\title{
H.P. Hanssen i Folketinget 1924-26
}

\author{
Af Hans Schultz Hansen
}

De danske sønderjyders førstemand H.P. Hanssen valgte ved Genforeningen i 1920 foreløbig at stå uden for dansk partipolitik. Først i 1923 lod han sig stille op som folketingskandidat for Venstre. Ved valget $i 1924$ kom han ind $i$ Folketinget, men allerede i 1926 forlod han efter eget ønske tinget ved folketingsvalget. Arkiv- og forskningsleder, dr.phil. Hans Schultz Hansen undersøger H.P. Hanssens motiver bag opstilling og mandatnedlæggelse samt de sager, han beskæftigede sig med.

\section{H.P. Hanssen i Folketinget - en skuffelse?}

For H.P. Hanssen blev tiden i dansk partipolitik kort. De to og et halvt år som folketingsmand for Venstre 1924-26 forblev en parentes i denne fremtrædende sønderjydes liv. Blandt hans samtidige vakte det hurtige farvel til Christiansborg undren. Det kaldte på en forklaring. En af H.P. Hanssens nære medarbejdere, redaktør C.J. Bech på Hejmdal, kom ind på det i Bogen om H.P. Hanssen fra 1948: "Da H.P. Hanssen ved folketingsopløsningen forud for valget i 1926 tog afsked med rigsdagsarbejdet og dermed afsluttede den gerning som parlamentari$k e r$, til hvilken han fra de unge år havde uddannet sig, var det uden bitterhed. En sådan følelse lå ham fjern, skønt hans deltagelse i dansk politik utvivlsomt havde været en skuffelse for ham. Nogen rettroende partigænger blev han aldrig. Vant til større forhold og videre udsyn, som han var, blev han på den danske rigsdag en fremmed, hvem de snævre partirammer efter hans korte ministertid ikke bød tilstrækkeligt virkerum for den sag, han havde viet sine kræfter. Hans tid forekom ham for kostbar til, at han skulde sætte sig ind i alt det, der skilte herhjemme, og som var baggrunden for dansk politik. Her havde han ingen interesser. Det var hans sønderjyske sag uvedkommende. Som minister havde han kunnet udrette noget, som almindelig rigsdagsmand fandt han ingen tilfredsstillelse i livet på Christiansborg. Og da tillige hans helbred begyndte at volde ham kvaler, sagde 
han farvel uden sorg. Han kendte politikerens vilkår og havde ikke gjort sig illusioner. " ${ }^{1}$

Laust Moltesen, der både var rigsdagskollega med H.P. Hanssen og hans ven gennem mange år, så det på samme måde: »Det var tydeligt at mærke, hvor fremmed han følte sig både $\mathrm{i}$ partimøderne og $\mathrm{i}$ salen. $\ll^{2}$

Bechs og Moltesens opfattelse skærpes af protokolsekretær Svend Thorsen, der om nogen har beskæftiget sig med sønderjysk partipolitik i mellemkrigstiden. Han beskriver H.P. Hanssen som "en halvgammel mand, dertil næsten udslidt«, der følte sig "træt og tilovers". Ifølge Thorsen var nationalitetskampens store optimist blevet pessimist, og han mente endog, at »H.P. Hanssens 15 sidste leveår står overvejende $i$ et tragisk lys «, ${ }^{3}$

Om der kan rokkes ved denne opfattelse af H.P. Hanssens folketingstid som en fiasko, er ikke godt at sige. Det kræver en nærmere undersøgelse, hvilket netop er hensigten med denne artikel. Selvom den måske ikke vil føre til et grundlæggende ændret syn på H.P. Hanssens korte åremål $\mathrm{i}$ dansk politik, må det dog under alle omstændigheder være interessant med et nærmere studium af, hvordan H.P. Hanssen kom ind i dansk partipolitik, hvilken position han fik, hvilke "sager « han beskæftigede sig med som folketingsmand, og hvordan hans exit fra dansk partipolitik blev.

Kildematerialet til undersøgelsen er dels trykte kilder som Hejmdal og Folketingstidende, dels utrykt materiale fra H.P. Hanssens arkiv, bl.a. hans brevveksling med Niels Neergaard og hans breve hjem til hustruen Helene hjemme i Nygade i Aabenraa.

\section{H.P. Hanssen og Venstre - en vanskelig forhistorie}

Da H.P. Hanssen stillede op til folketingsvalget i 1924, var han langtfra en novice som parlamentariker. 1896-1908 var han medlem af den preussiske landdag og 1906-18 af den tyske rigsdag, valgt af dansksindede sønderjyder. Som sådan opfattede han sig først og fremmest som repræsentant for en befolkning og ikke for et politisk parti. ${ }^{4}$

Ligesom andre førende danske sønderjyder måtte H.P. Hanssen forholde sig til den danske partistrid mellem Højre og Venstre. Mens den sønderjyske danske presse og de fleste dansksindede i den ældre generation holdt med Højre i forfatningskampen, særlig på grund af Højres krav om et stærkt dansk forsvar, lå H.P. Hanssens og adskillige 
andre unges sympati hos Venstre. Det var navnlig til kongerigets unge venstremænd, han knyttede sine kontakter. Mange af dem fandt ved Venstres splittelse i 1905 vej til Det radikale Venstre. H.P. Hanssen stod dog med sin udpræget grundtvigske indstilling nærmere I.C. Christensens, Niels Neergaards og Klaus Berntsens Venstre. ${ }^{5}$

Da det slesvigske spørgsmål blev genåbnet efter Tysklands nederlag i 1918, var forventningen, at H.P. Hanssen efter Nordslesvigs genforening med Danmark ville slutte sig til Venstre. ${ }^{6}$ I november 1918 udtalte H.P. Hanssen imidlertid, at han ikke straks ville tilslutte sig et politisk parti, og at han forestillede sig en overgangsperiode, hvor de nyvalgte folke- og landstingsmænd fra Sønderjylland udgjorde deres egen gruppe i den danske rigsdag. Så kunne de dels tale med én stemme i de særligt sønderjyske sager, dels få tid til at blive fortrolige med dansk partipolitik. Denne tanke vandt oprindeligt tilslutning både i Sønderjylland og kongeriget, men den blev i løbet af 1919 umuliggjort af grænsestriden mellem Aabenraa-, Flensborg- og Danevirkefolk.?

Denne strid blev skærpet, da H.P. Hanssen den 24. juni 1919 blev optaget som midlertidig minister for sønderjyske anliggender i det radikale ministerium Zahle. Over for C.Th. Zahle havde H.P. Hanssen fremhævet, at han ikke sigtede mod en partipolitisk tilslutning til regeringen, men alene mod den bedst mulige ledelse af genforeningsprocessen. Derfor ønskede han, at oppositionen blev orienteret herom før udnævnelsen. Zahle kunne imidlertid ikke dy sig for at score den politiske gevinst for regeringen og lod udnævnelsen sprænge som en bombe. Det gjorde med ét slag H.P. Hanssen vældig upopulær i Venstre og Konservative og direkte forhadt $\mathrm{i}$ de voksende kredse $\mathrm{i}$ de to partier, som gik ind for en sydligere grænse end Krusålinjen. Også på hjemmebanen i Sønderjylland bar ministerudnævnelsen ved til bålet. Vælgerforeningen blev splittet under den skærpede grænsestrid. I efteråret 1919 fandt et nyvalg sted, hvorefter Aabenraa-fløjen alene kunne bevare flertallet og H.P. Hanssen sin ministerpost ved hjælp af Sønderjysk Arbejderforenings stemmer. ${ }^{8}$

H.P. Hanssens ministertid sluttede brat, da Christian $X$ afskedigede ministeriet Zahle den 29. marts 1920 og dermed gav bolden op til Påskekrisen. Der blev udskrevet folketingsvalg, som resulterede i dannelsen af et venstreministerium under Niels Neergaard. Denne tilbød H.P. Hanssen den ledende post $i$ en sønderjysk tremandskommission, men da den nye regering sogte at udvirke en internationali- 
sering af 2. zone med en afstemning 15 år ude $\mathrm{i}$ fremtiden, afviste H.P. Hanssen at medvirke. ${ }^{9}$ Han fandt, at man dermed løb en høj risiko for at få genoptaget grænsespørgsmålet i en for Danmark ugunstig situation med et stærkt Tyskland, og at det $\mathrm{i}$ værste fald kunne føre til genafståelse af hele Nordslesvig eller dele deraf.

H.P. Hanssen genoptog herefter tanken om en særlig sønderjysk rigsdagsgruppe. ${ }^{10} \mathrm{I}$ april 1920 forestillede han sig, at en sådan fraktion kunne blive »tungen på vægtskålen « mellem de to blokke i dansk politik, Socialdemokratiet-Radikale Venstre og Venstre-Konservative Folkeparti. Dermed kunne man udnytte situationen til at opnå det bedst mulige for grænselandet. Den sønderjyske gruppe var kun udset til at eksistere i den første valgperiode efter Genforeningen. Derefter skulle sønderjyderne fordele sig på de danske partier. Det viste sig hurtigt, at H.P. Hanssen ikke kunne gore regning på Flensborgfolkenes medvirken. De gik tværtimod i gang med at organisere lokale venstrevælgerforeninger. Heller ikke blandt H.P. Hanssens tilhængere var der ubetinget tilslutning til tanken. I Haderslev Østeramt betingede man sig, at en sønderjysk gruppe fik tilknytning til Venstre. En forhåndskontakt til Venstres undervisningsminister Jacob Appel lod forstå, at en sådan konstruktion kunne accepteres af Venstre. Under indtryk af holdningen i Østeramtet vedtog et flertal at ændre gruppens navn til Det sønderjyske Venstre. Det vedtoges at indlede forhandlinger med Venstre $i$ kongeriget om en alliance ved fordelingen af tillægsmandater; til gengæld skulle Venstre ikke opstille egne kandidater i Nordslesvig. H.P. Hanssen accepterede den drejning, hans egen plan hermed fik, formentlig fordi gruppen så kunne holdes samlet.

Afgørende for planens videre skæbne blev nu Venstres holdning. Det viste sig snart, at Appels positive holdning til et særligt sønderjysk Venstre savnede opbakning i partiledelsen. I.C. Christensen, der i særlig grad var forbitret på H.P. Hanssen, afviste helt tanken. Neergaard fandt, at Venstre frem for alt måtte støtte de rene venstreforeninger, som var under dannelse, og de kandidater, de opstillede. Dermed var der $\mathrm{i}$ realiteten ingen vej frem for et særligt sønderjysk parti sammen med Venstre. En vej frem med Venstre imod sig troede ingen rigtig på. H.P. Hanssen og hans nære meningsfælle, tidligere landdagsmand Nis Nissen, Viby, tilrådede en opløsning af Det sønderjyske Venstre. Begge ville blive stående uden for partierne og ikke stille op ved folketingsvalget. Efter denne erklæring besluttede Det 


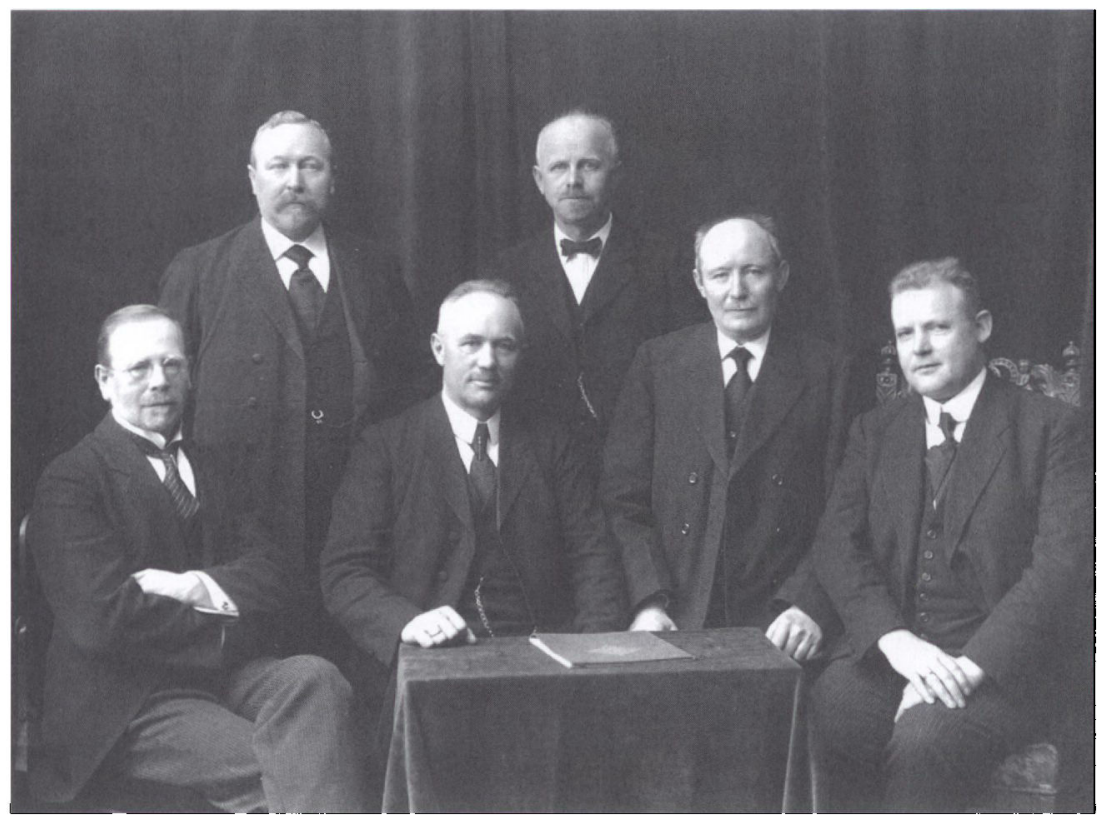

Seks af Venstres syv sonderjyder på tinge $i$ 1920. Fra venstre folketingsmændene Anders Lebeck, Christian Ernst Christensen, P.J. Refshauge og Mads Gram samt landstingsmændene Hans Jefsen Christensen og Andreas Karberg. Landstingsmand H.D. Kloppenborg-Skrumsager er ikke med på billedet. Elfelt foto $i$ Museum Sønderjylland - ISL.

sønderjyske Venstre at opløse sig selv. For H.P. Hanssens vedkommende skete det ikke uden bitterhed og med skarp kritik af Venstres sønderjyske politik.

Ved valget den 21. september 1920 fik Aabenraa-fløjen ikke desto mindre et godt valg. Alle fire nyvalgte folketingsmænd for Venstre, Anders Lebeck, Christian Ernst Christensen, P.J. Refshauge og Mads Gram, var H.P. Hanssens politiske lærlinge. Men mesteren selv manglede.

\section{H.P. Hanssen stiller op for Venstre i 1923}

I sommeren 1923 rykkede et folketingsvalg tættere på. I september 1924 ville den fireårige valgperiode udløbe. Venstres ledelse forudså, at partiets strålende resultat i Sonderjylland ved folketingsvalget i 1920 med $48 \%$ af stemmerne og fire folketingsmandater kunne blive 
endog meget vanskeligt at gentage. Der måtte en stemmesluger på banen. En sådan var H.P. Hanssen. De to siddende folketingsmænd for Venstre i Haderslev og Aabenraa kredse, domæneforvalter P.J. Refshauge og redaktør Anders Lebeck, blev derfor af Venstres bestyrelse anmodet om at give afkald på genopstilling. ${ }^{11}$

Den 18. september 1923 mødte to deputationer på tilsammen 28 mand op hos H.P. Hanssen i hjemmet i Nygade i Aabenraa. De kom fra Haderslev og Aabenraa opstillingskredse og havde henholdsvis Jørgen From fra Fjelstrup og borgmester Holger Fink fra Aabenraa som talsmænd. De menige medlemmer var H.P. Hanssens tro venner og støtter. Deputationernes ærinde var at formå H.P. Hanssen til at stille op som folketingskandidat på Venstres liste. De to skriftlige opfordringer erklærede kort underskrivernes tillid til H.P. Hanssen som samlende skikkelse og gav ham lofte om en stor vælgeropbakning. Mere direkte var de to ordførere i deres taler. Jørgen From opfordrede indtrængende H.P. Hanssen til »ikke nu at svigte sine gamle vælgere, venner og meningsfæller, som han havde repræsenteret $i$ så mange år i Berlin«. Holger Fink sagde til H.P. Hanssen, "at det nu var hans pligt at bøje sig for deres enstemmige ønske og krav«. Der blev lagt pres på. ${ }^{12}$

Dette blev yderligere understreget ved, at Refshauge og Lebeck i breve til H.P. Hanssen erklærede at ville vige pladsen for ham, således som de $\mathrm{i}$ lighed med hans andre meningsfæller blandt de nyvalgte rigsdagsmænd allerede havde lovet ham i 1920. Lebeck fandt, "at din genindtræden $\mathrm{i}$ aktiv politik væsentlig ville bidrage til at give vor nationale politik fasthed og fæstne forståelsen for rigtigheden af vor nye sydgrænses dragning “. Svend Thorsen mener, at Refshauge gerne opgav sin folketingskarriere til fordel for sine mange andre hverv, mens Lebeck inderst inde helst ville have beholdt sin status som folketingsmand. ${ }^{13}$

H.P. Hanssen udbad sig en uges betænkningstid, da der var flere forhold, som han ville have på plads først. Noget var af privat karakter, andet blev afklaret ved en samtale med Jacob Appel, men hovedtvivlsspørgsmålet måtte H.P. Hanssen afhandle med Venstres leder. Den 21. september skrev han til Neergaard, at han nu var klar til opstilling, begrundet med, "at jeg til slut følte et større ansvar ved at sige nej end ved at sige ja til den af mine gamle venner og meningsfæller på ny til mig rettede indtrængende opfordring «. Særlig fremhævede H.P. Hanssen, »at jeg som politiker er sønderjysk specialist«. 
Han opregnede sin lange politiske erfaring og fortsatte: "I alt, hvad der vedrører Sønderjylland og i tilknytning dertil vort forhold til Tyskland, føler jeg derfor som sagkyndig et særligt ansvar, og dette vil medføre, at jeg i disse spørgsmål udelukkende lader mig lede af min egen overbevisning om, hvad der tjener folket og riget bedst, og aldrig vil kunne bøje af derfra af hensyn til partiformål. I disse spørgsmål må jeg derfor fra første færd af forbeholde mig helt frie hænder.« Om alle andre politiske spørgsmål udtalte han blot, »at Venstres program ikke indeholder noget, som jeg ikke kan tiltræde «.

Neergaard svarede allerede dagen efter. Han fandt ikke, at H.P. Hanssens forbehold ville volde problemer for partiet: "Det er $\mathrm{i}$ virkeligheden kun et udtryk for den frihed, som ethvert medlem har i spørgsmål, hvor partiets program ikke har fastslået en bestemt retningslinje.« For en sikkerheds skyld ville han dog forelægge sagen for bestyrelsen. Neergaard fortsatte: "Jeg kan ikke slutte dette brev uden at bringe Dem min oprigtige tak for den beslutning, De har taget. Den har vakt stor glæde både i ministeriet og partiet, og jeg kan for mit eget vedkommende sige, at det er længe siden noget har glædet mig mere... jeg er sikker på, at vort samarbejde vil blive det bedst mulige. « Neergaard har sikkert ment, at der var nogle skår, som skulle klinkes efter hans og H.P. Hanssens uenighed om internationaliseringen af 2. zone i 1920 . Allerede to dage senere kunne Neergaard vende tilbage med oplysning om, at H.P. Hanssens forbehold var accepteret af partiet. ${ }^{14}$ Dermed var sagen afklaret for H.P. Hanssen, og han accepterede opfordringen fra Venstre $i$ de to valgkredse. ${ }^{15}$

Det er formentlig sjældent sket $i$ dansk partihistorie, at en folketingskandidat for at lade sig opstille har betinget sig politisk handlefrihed på så væsentligt et politisk felt. Få år tilbage havde grænsespørgsmålet splittet nationen, og det havde stadig en indenrigspolitisk betydning - for slet ikke at tale om en udenrigspolitisk. Derfor er det bemærkelsesværdigt, at Neergaard valgte at sidestille det med etiske og religiøse sager, hvor folketingsmedlemmer efter Venstres tradition kunne bryde partidisciplinen. Det viser, at det var vigtigt for Venstre, at H.P. Hanssen stillede op i Sønderjylland og skaffede partiet mange stemmer, men det må også afspejle, at Neergaard og de andre venstreledere anså det for usandsynligt, at H.P. Hanssen ville få behov for at gøre sit forbehold gældende. Det kan kun betyde, at Venstres ledelse nu var indstillet på at følge H.P. Hanssens linje i det sønderjyske spørgsmål. Dette falder i hvert fald fint i tråd med Neer- 


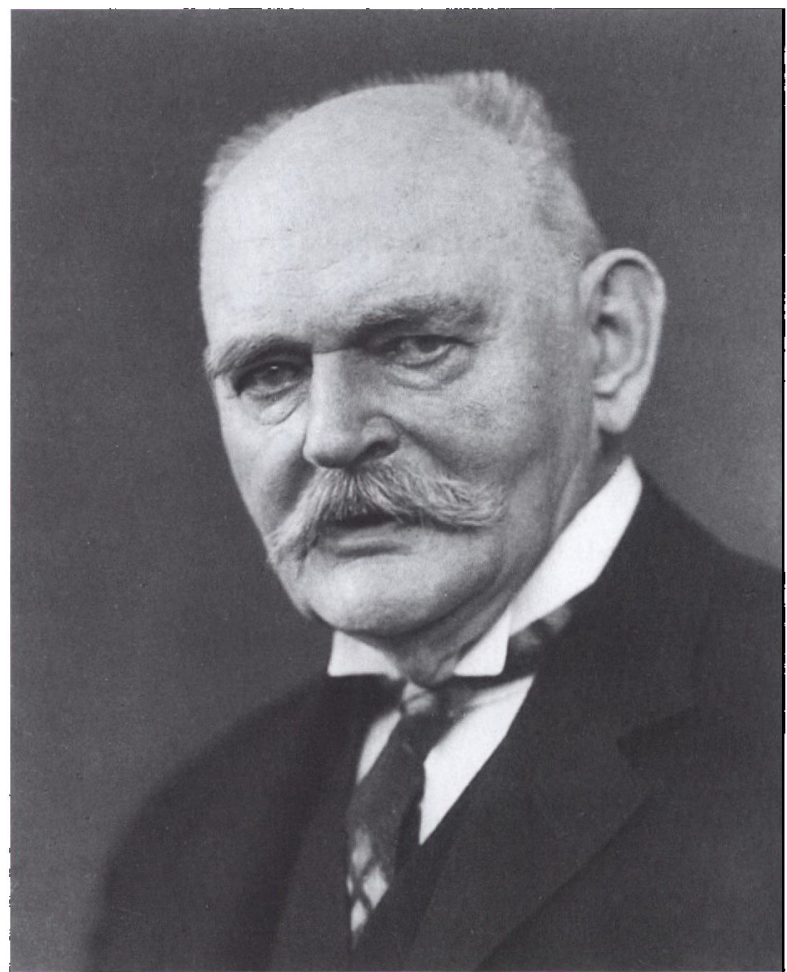

Niels Thomasius Neergaard (1854-1936) var Venstres statsminister 1908-09 og 192024 samt finansminister 1908, 1910-13 og 1926-29. Han huskes $i$ dag måske snarere som forfatter til det solide trebindsvark Under Junigrundloven om Danmarks politiske historie 1848-66. Foto: Museum Sonderjylland - ISL.

gaards udtalelse i Folketinget en lille måned senere, den 18. oktober 1923: "Jeg har sagt det før, og jeg gentager det her: Grænsen ligger fast, og der vil fra regeringens side blive giort alt for at opretholde den. Danmark spekulerer ikke hverken i Tysklands ulykke eller i noget andet nabolands ulykker. ${ }^{16}$ Konkret betød det, at Neergaard afviste at støtte private bestræbelser på at udnytte den tyske inflationskrise til at hverve blandt sydslesvigerne for landsdelens tilbagevenden til Danmark. H.P. Hanssens opstilling og Neergaards tale var dermed en kold spand vand $i$ hovedet på Flensborgfolkene.

H.P. Hanssens indtræden i dansk politik vakte - allerede før hans betænkningstid var udløbet - en mægtig opsigt i pressen. ${ }^{17}$ De fleste kommentarer var positive. Navnlig radikale blade og venstreblade så 
hen til, at H.P. Hanssen nu ville komme til at indtage den placering $\mathrm{i}$ dansk politik, som tilkom ham i kraft af hans store erfaring. Nogle så endda hen til, at H.P. Hanssen kunne blive en samlende kraft $i$ en fornyelse af det politiske liv med en opblødning af de hårdt optrukne fronter mellem partierne.

Mange aviskommentarer pegede på, at Nis Nissen kort tid forinden havde ladet sig opstille som folketingskandidat i Sønderborgkredsen for Det radikale Venstre. Spekulationer opstod om, at de to kampfæller fra udlændighedstiden og grænsestriden ville trække deres respektive partier imod hinanden og måske endda bevirke en genforening af Venstre. Det var dengang mindre end 20 år siden, at Det radikale Venstre i 1905 var brudt ud af det daværende Venstrereformparti. For nogle få var dette en forhåbning, for flere - navnlig i de konservative blade - en frygt, da det ville sætte en stopper for VKsamarbejdet. I den konservative Haderslev Stiftstidende var det A. Svensson meget om at gøre at skildre H.P. Hanssens genindtræden i Venstre, som om partiet dermed havde undsagt de Flensborgvenlige kredse i partiet - selvfølgelig i håb om, at de så ville finde over til Det konservative Folkeparti. ${ }^{18}$

Imidlertid ramte Østsjællands Folkeblad hovedet på sømmet, når det fastslog: "Alt $i$ alt er det da sådan, at denne bølgende nyorienteringsdebat $i$ virkeligheden mere afspejler stemninger og forhåbninger inden for de bestående danske partier, end den er udtryk for planer hos H.P. Hanssen. ${ }^{19}$ H.P. Hanssens eget blad, Hejmdal, bekræftede dette. ${ }^{20}$ Den nye folketingskandidat gjorde det selv i et interview i København, hvor hans sidste ord var: "Man må i øvrigt ikke vente, at jeg vil tage en fremskudt stilling i de almindelige politiske anliggender. « $^{21}$ Intet tyder på, at H.P. Hanssen havde ambitioner om en fremtrædende stilling i Venstre. Forbeholdet i brevet til Neergaard viser mere end noget andet, at H.P. Hanssen gik ind $i$ dansk partipolitik for at videreføre den linje, han altid havde fulgt: at virke for sine dansksindede sønderjyske landsmænd.

H.P. Hanssen valgte da også at tale om "Stillingen og opgaverne i Sønderjylland «, da han blev bedt om at tale på det jyske Venstres delegeretmøde i Skive i december 1923. ${ }^{22}$ Her fik venstrefolkene en belæring om, hvad H.P. Hanssen ville med et folketingsmandat. Først beskrev han landsdelens befolkningsmæssige og økonomiske udgangspunkt og indskærpede tilhørerne: "Nordslesvig var således, da det blev genforenet med Danmark, et folketomt og kapitalfattigt land. 
Det må De for det første holde Dem klart for øje, når der er tale om fremtidens politiske opgaver.« H.P. Hanssen fortalte dernæst om den nationale stilling $\mathbf{i}$ »den truede firkant «: "Her mødte foruden byerne Aabenraa og Tønder og flækken Højer tre landsogne med tyske flertal. I 16 andre sogne blev der afgivet over 30 procent tyske stemmer, deraf over 40 procent i seks og 49 procent i fire. Alle disse sogne hører til den tyndest befolkede del af Sonderjylland «, og han appellerede: "Dette bør De ligeledes holde Dem klart for øje, når der er tale om fremtidens politiske opgaver.«

Den nye folketingskandidat sagde om selve grænsespørgsmålet: "Alle ansvarlige danske politikere er enige om, at grænsen ligger fast. « Han nævnte også de tyske socialdemokraters anerkendelse af 1920grænsen i den netop indgåede Stauning-Wels-aftale mellem danske og tyske socialdemokrater af 25 . november 1923 . Men andre tyskere onskede at flytte grænsen nordpå, og derfor var det ikke muligt at slappe af: »Vor sydgrænse er stærk, fordi den hviler i sig selv, det vil sige på folkets frie vilje. Dette betyder mere end en partimæssig, mere end en statsretslig bindende anerkendelse. Men vor politik bør gå ud på at styrke den. Og den vil styrkes i samme grad som den danske befolkning nord for grænsen vokser talmæssigt, tiltager i velstand og højnes kulturelt.« Og igen fik de forsamlede venstrefolk en klar henstilling: "At skabe de ydre betingelser herfor er vigtige rigsopgaver, som må løses, selv om det kræver betydelige finansielle ofre."

I forlængelse heraf forsvarede H.P. Hanssen de fire små sønderjyske amter. Der var på grund af de mange opgaver under overgangen fra tysk til dansk styre et stærkt behov for ekstra embedsmænd. Så betød en årlig ekstraudgift på 30-40.000 kr. mindre. En sådan udtalelse kunne nok få det til at gibbe i mangen jysk venstrebonde. H.P. Hanssen ønskede også statsinstitutioner til Sønderjylland, bl.a. et sønderjysk landsarkiv: "Strenge sparekrav må her ligesom lokale interesser vige for hensynet til, hvad der ved at styrke vor sydgrænse fremmer hele rigets tarv«. Sparsommeligt anlagte venstrefolk var dermed advaret om konsekvenserne af at få den nye kandidat med i folden.

\section{H.P. Hanssen i valgkamp 1924}

I februar og marts 1924 blev H.P. Hanssen opstillet på delegeretmøder i Haderslev og Aabenraa kredses Venstre. Det var en formalitet, og han blev begge steder enstemmigt valgt. I Haderslev redegjorde 
H.P. Hanssen for sin stilling til Venstre. Han fremhævede, at han i sin pureste ungdom havde sluttet sig til Venstre, skrevet venstreindlæg i Højskolebladet og været sønderjysk korrespondent til en række venstreblade i kongeriget. Derfor kunne det ikke komme som nogen overraskelse, at han stillede op for Venstre. Det betød selvfølgelig, at han kunne gå fuldt og helt ind for Venstres partiprogram. Han fremhævede således balance på statsbudgettet, slankning af administrationen, stop for flere og højere direkte skatter, men om nødvendigt en luksusafgift f.eks. på biler. H.P. Hanssen gik også ind for en højere kurs på kronen, så den igen nåede op på sin »normale højde“, dvs. parikursen. På det sociale område ønskede han en øget kontrol med arbejdsløshedskasserne, så de ydede bedst mulig støtte til dem, der ville, men ikke kunne få arbejde, og forhindrede, at »dagdrivere« udnyttede kasserne. Udstykningspolitikken havde også H.P. Hanssens sympati; den havde jo også en national mission i Sønderjylland. Denne landsdel var på ny H.P. Hanssens hovedærinde, som fyldte mest $i$ programtalen. Denne del svarede indholdsmæssigt til talen i Skive. ${ }^{23}$

I Aabenraa sluttede H.P. Hanssen sin tale således: „Før Genforeningen hævdede vi altid, at vi var en befolkning og ikke et parti, dvs. at klasseinteresser må vige for samfundsinteresser. Jeg er nu opstillet for et parti, for Venstre. Men Venstre er ikke et klasseparti, men et folkeparti, der ønsker at varetage hele samfundets interesser. Det er ud fra dette grundsyn, jeg ser min opgave, og det er ud fra det synspunkt, at jeg ønsker at varetage hele landsdelens interesse, både for by og land, både arbejdere og arbejdsgivere, ud fra den grundsætning, som Rasmus Rask gav udtryk for i sit ord: Sit fædreland skylder man alt, hvad man kan udrette. ${ }^{24}$

Få dage efter mødet i Aabenraa udskrev statsminister Neergaard folketingsvalg til den 11 . april $1924 .{ }^{25}$ Snart var valgkampen i fuld gang. H.P. Hanssen holdt sit første valgmøde i Rødekro den 21. marts. Som på de følgende møder var H.P. Hanssen eneste taler. Han ønskede ikke at deltage i valgmøder, hvor de andre partiers kandidater også talte, således som man brugte det nord for Kongeåen. Hans begrundelse var, at disse møder gav for ringe kontakt med vælgerne, når der var anmeldt otte partier: "Skal alle kandidater tale efter hinanden, og alle lægge beslag på tiden, da sættes dermed den stedlige vælgerbefolkning ud af spillet.« Derfor ville han heller ikke deltage $\mathrm{i}$ andre partiers valgmøder, hvorimod han gerne så, at andre partiers folk kom til hans møder, forudsat at han selv kunne lede og præge møderne, så de blev venstre- 
møder. Specielt var han uenig $i$, at det var vælgermødernes formål at trække partiernes forskellige holdninger skarpere op. Det kunne være farligt i grænselandet, hvor man ofte skulle kunne finde sammen på tværs for at holde den nationale front. ${ }^{26}$

Sikkert lå der også taktiske overvejelser bag dette. I et flerkantet vælgermøde ville H.P. Hanssen fremstå som en partipolitiker blandt andre. Dermed ville den historiske pondus, han besad som de danske sønderjyders nationale lederskikkelse, ikke udøve den samme tiltrækning på vælgerne, og han ville få sværere ved at udfolde sine særlige sønderjyske standpunkter.

Hejmdals referater af H.P. Hanssens møder lod dem tilsvarende fremstå nærmest som nationale tilkendegivelser. Det gjaldt særlig i begyndelsen af valgkampen. Reportagen fra mødet i Genner sluttede således: "Mødet i Genner blev et godt møde, et godt nationalt møde, der bar vidnesbyrd om en stærk vilje til den 11 . april at møde mand af hus for at befæste stillingen over for den fælles modstander, tyskerne, og tillige en fast besluttethed på at være med at sætte H.P. Hanssen ind på den danske rigsdag med stærk støtte i befolkningen. " Sognerådsformand Rasmus Callesen fra Lerskov lå helt på samme linje. Som mange sønderjyder følte han sig fremmed over for dansk partipolitik: »Vi må jo tilstå, at vi ikke er så godt organiseret til dette valg, som vi var det, når vi gik til valg i gamle dage. $\mathrm{Nu}$ fortaber vi os i partikampene, men det er nødvendigt, at vi får valgarbejdet organiseret og får alle danske stemmer frem, hvad parti de end hører til, at ikke tyskerne procentualt set skal gå frem. Og vi har jo kun grund til at være glade ved at gå til valg denne gang, da vi atter kan stemme på vor gamle fører H.P. Hanssen. Selv om vi nu skal gå ind under danske forhold, så er der dog meget, der hernede ser anderledes ud end oppe nordpå, og der trænger vi til kyndige og stærke mænd. En sådan får vi med H.P. Hanssen, og jeg vil sige: Lad os møde mand ved mand og stemme på H.P. Hanssen. Et leve for, at vi får en rigsdag med den rette samfundsfølelse, en rigsdag, der ikke først og fremmest tænker på partiernes, men på det heles vel! « ${ }^{27}$

En tilsvarende skepsis ved partierne delte en anden national veteran, væver Th. Kaufmann i Bovrup, der i Felsted erklærede, at han ikke så sig i stand til at stemme på et bestemt parti, men nok på en bestemt mand. Der var gode mænd i alle partier, men det skulle være "en mand hernede fra, ikke en fra København eller andetstedsfra", og så kunne man ikke få nogen bedre end H.P. Hanssen. ${ }^{28}$ 
H.P. Hanssen var derfor sikkert i overensstemmelse med sine vælgere, når han på valgmødet $i$ Uge luftede en vis skepsis over for den rigsdanske måde at fore valgkamp på: "Jeg betragter det ikke som min opgave at tale ilde om de andre partier. Jeg tror, at vi ligesom englænderne bør betragte vore politiske modstandere som gentlemen, møde dem med en ærlig overbevisning og i stedet for den stadige nedrakning fremhæve de lyse sider ved det parti, man har sluttet sig til. ${ }^{29}$

H.P. Hanssen holdt endvidere valgmøder i Varnæs, Hoptrup, Hyrup, Løjt, Christiansfeld, Kliplev, Bolderslev, Haderslev og Aabenraa. ${ }^{30}$ Selv om valgmøderne beholdt et nationalt præg, fik de partipolitiske spørgsmål en større vægt sidst i valgkampen, især i Kliplev, hvor H.P. Hanssen ret detaljeret gennemgik Venstres partiprogram. På kant med mange venstrevælgere var han dog nok, når han her udtalte sig imod de populære krav om besparelser: »Der er to måder at spare på: at spare på skillingen og at tjene daleren, og den sidste måde er den fornøjeligste .... ${ }^{31}$

\section{Valgets resultat}

Valget den 11. april 1924 var trods H.P. Hanssens opstilling ikke gunstigt for Venstre. I Sønderjylland gik partiet tilbage fra 24.907 stemmer i 1920 til 17.118 stemmer i 1924 eller fra $48 \%$ til $30 \%$ af de afgivne stemmer. $^{32}$ Det gav kun to mandater mod fire i 1920. Også i H.P. Hanssens kredse var der stærk tilbagegang for Venstre. I Haderslevkredsen gik Venstre tilbage fra 33 til 24\%, i Aabenraakredsen fra 46 til $29 \%$. Sammenlignet med hele Sønderjylland lå tilbagegangen i Aabenraakredsen på gennemsnittet, mens den ikke var helt så udtalt i Haderslevkredsen.

Det var ventet, at Venstre ville gå tilbage i Sønderjylland. Resultatet fra 1920 var urealistisk højt. Mange af de nationale ledere, som sønderjyderne havde tillid til, stillede da op for Venstre, og det blev udslagsgivende for stemmeafgivningen hos de mange, som var uden kendskab til dansk partipolitik. Venstres mål med opstillingen af H.P. Hanssen var at begrænse denne tilbagegang. Man kan ikke sige, at det blev nået.

H.P. Hanssen opnåede som forudset et sikkert valg til Folketinget på et kredsmandat, men valgresultatet afspejlede mere hans skæbne som hovedperson i græensestriden end hans tidligere stilling som de danske sønderjyders førstemand. 
H.P. Hanssens personlige stemmetal i Haderslev og Aabenraa valgkredse var hhv. 2.087 og 2.198. Det svarede i begge kredse til $92 \%$ af de stemmer, der faldt på Venstre. Opbakningen blandt de to kredses venstrefolk var således massiv. Men ellers slog H.P. Hanssen ikke igennem som den samlende skikkelse blandt de sønderjyske venstremænd, således som hans fortid kunne begrunde. I de andre kredse stemte kun få på ham personligt. Højst nåede han i Røddingkredsen med 210 stemmer og i Løgumklosterkredsen med 176. I alt fik H.P. Hanssen 4.854 personlige stemmer. Hans nærmeste konkurrent og svorne modstander blandt venstrekandidaterne var Flensborgmanden, amtsforvalter C.O. Pedersen. Han var opstillet i Sønderborg og Løgumkloster kredse og fik i alt 3.677 personlige stemmer, herunder en del fra Tønderkredsen. Grænsestriden satte her stadig sit præg på mange venstrevælgeres sind. I Røddingkredsen og Augustenborgkredsen stod de to lokale venstrekandidater Mads K. Gram og Chr. E. Christensen stærkt, og her var der ikke mange løse venstrestemmer at hente for H.P. Hanssen.

H.P. Hanssens beskedne personlige stemmetal uden for hans egne to kredse skyldtes endelig, at Det radikale Venstre opstillede Nis Nissen i Sønderborg, Augustenborg og Rødding kredse. Tilhængere af Aabenraa-retningen uden for Haderslev og Aabenraa kredse anså utvivlsomt H.P. Hanssens valg for sikret under alle omstændigheder. Derfor gav adskillige formentlig deres stemme til Nis Nissen for også at sikre ham valg. Ved at stemme på H.P. Hanssen og dermed give ham et "overskud « af stemmer $\mathrm{i}$ forhold til det nødvendige for at opnå valg, risikerede de omvendt indirekte at stemme flensborgmanden C.O. Pedersen ind i Folketinget. ${ }^{33}$ Det lykkedes at få Nis Nissen valgt ind med 3.999 personlige stemmer.

\section{H.P. Hanssen som nybagt folketingsmand}

Valget gav også i det øvrige land markant tilbagegang til Venstre. Partiet tabte syv mandater. Neergaard trådte tilbage som statsminister. I stedet fik Danmark sin første socialdemokratiske regering under Th. Staunings ledelse og med Det radikale Venstre som støtteparti.

Mister et parti regeringsmagten, bliver den interne kamp om posterne hård. Først tager de afgående ministre fra, og der bliver desto færre at fordele mellem de menige gruppemedlemmer - og næppe 


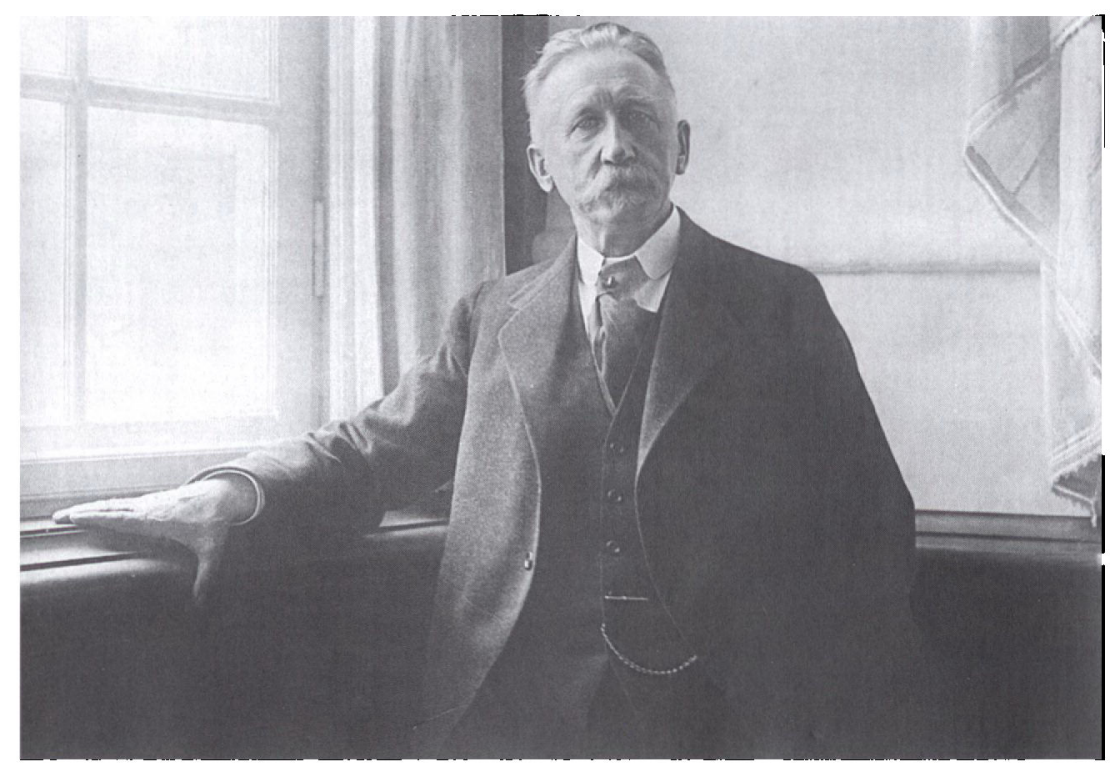

H.P. Hanssen fotograferet i den danske rigsdag. Foto: Museum Sønderjylland - ISL.

nogen betydende til de nyvalgte. Det fik H.P. Hanssen også at mærke. Ifølge datteren Ingeborg Refslund Thomsen havde han ønsket sig en plads i Udenrigspolitisk Nævn. ${ }^{34}$ Hertil valgte partiet imidlertid tre andre folketingsmedlemmer. At man udpegede partiets leder Neergaard og partiets udenrigspolitiske ekspert Laust Moltesen, var der intet at sige til. Moltesen var i øvrigt som født i Råhede syd for Ribe sønderjyde og dertil en mangeårig ven af H.P. Hanssen; han blev udenrigsminister, da Venstre igen dannede regering i 1926. Som den tredje udpegede Venstre Dannevirkemanden J.S. Vanggaard. H.P. Hanssen var utvivlsomt mere kvalificeret end Vanggaard, men denne sad i forvejen i nævnet, og måske drejede det sig også om at sikre en repræsentation af partigruppens højrefløj. H.P. Hanssen blev i stedet suppleant for Moltesen. Til gengæld blev han fuldgyldigt medlem af det udvalg, der skulle nedsættes $i$ henhold til grundlovens $\S 45$ til at udpege medlemmer af udvalg, hvor der både skulle være repræsentanter fra Folke- og Landsting. Det var næppe nogen tung post. ${ }^{35}$

I sin tid som landdags- og rigsdagsmand i Berlin havde H.P. Hanssen flittigt sendt breve hjem til sin hustru. Som nybagt folketingsmand lovede han straks i sit første brev fra København den 29. april 
1924: »Det er nok bedst, at jeg straks genoptager den gamle skik med brevskriveri « - og det løfte holdt han. ${ }^{36}$ I samme brev beskrev han, hvorledes han var blevet modtaget i partiet: „Vi mødte i går til partimøde kl. 11. Jeg fulgtes med Moltesen op i salen og fik min plads ved hans side, yderst på venstre fløj. I Tyskland ville man tillægge dette betydning. Her er det ikke tilfældet. Lige over for mig sidder $\mathrm{H}$. Jefsen Christensen, ved min anden side Jakobsen Rudme. Du har vel set, at jeg blev valgt ind i partiets bestyrelse. Der var ellers rejst en bevægelse imod mit valg under påskud af, at jeg vilde søge samarbejde med de Radikale." Nogle venstrefolk nærede øjensynlig mistro mod H.P. Hanssen, men de udgjorde et mindretal. Valget som medlem af gruppebestyrelsen var et udtryk for Venstres anerkendelse af H.P. Hanssens politiske erfaring.

I folketingssalen undgik H.P. Hanssen tilsvarende mange nyvalgte folketingsmedlemmers skæbne, at blive placeret i "grebningen ", i folketingssalens bageste række af pladser. I stedet fik han plads i fjerde række set fra talerstolen. ${ }^{37}$ Her fik han sæde mellem fhv. handelsminister Jørgen Christensen og J. Clausager, »en stortskåren jysk bonde». Med disse sidemænd var H.P. Hanssen ifølge sit brev til Helene godt tilfreds.

Om modtagelsen $\mathrm{i}$ tinget berettede H.P. Hanssen videre i sit første brev hjem: "Jeg er blevet modtaget med venlighed, - dog ikke overdreven. Højre fløj inden for partiet er øjensynlig ængstelig for, at jeg skal have radikale tilbøjeligheder, en del af de Radikale er kølige og reserverede, og af Højre har kun enkelte hilst venligt på mig. Derimod er Socialdemokraterne meget venlige. Stauning, Borgbjerg, Hauge, Steincke, Nina Bang og Friis Skotte har alle ulejliget sig hen for at hilse på mig og byde mig velkommen. Ligeså grev Moltke, med hvem jeg havde lejlighed til at føre en kort samtale. Hvad Venstre angår, tiltaler miljøet mig. Det falder, hvad personer og karakterer angår, ret nøje sammen med, hvad jeg har arbejdet med i Nordslesvig. Der er mange stortskårne kraftige ansigter, vist også meget stivsind og en dygtig portion snæversyn hos en del, men gennemgående typer hvis fortrin og mangler jeg kender, og mellem hvem jeg føler mig hjemme ...«

Brevet viser, at heller ikke H.P. Hanssens modstandere på tinge fra grænsestriden havde glemt ham. For dem var han stadig et stridens tegn. Det gjaldt især hos de Konservative og højrefløjen i Venstre. Når omvendt nogle Radikale gav H.P. Hanssen en kølig modtagelse, 
skyldes det sikkert, at de havde regnet ham for en af deres og nu var ærgerlige over hans tilslutning til "arvefjenden " Venstre. Disse følelser nærede Socialdemokraterne ikke. Deres venlige modtagelse af H.P. Hanssen var måske også en afsmitning af hans gode forhold til det tyske søsterparti. Brevet viser endelig, at H.P. Hanssen fik et godt førstehåndsindtryk af de menige venstrefolk. Alt $i$ alt var hans debut som folketingsmand faldet rimeligt tilfredsstillende ud.

H.P. Hanssen oplevede hurtigt, at folketingsmandatet indebar et stort arbejde. Allerede ved udgangen af maj måned skrev han hjem: »Jeg kan nok indse, at jeg får meget at bestille her. Jeg er jo nødt til at sætte mig ind i mangfoldige sager, og min korrespondance svulmer stærkt op. Det er, hvad jeg længe har frygtet for ...«"«8 Medvirkende hertil var, at sønderjyderne som i H.P. Hanssens yngre år (mis)brugte ham som deres konsulent i utallige spørgsmål. I januar 1925 skrev han til sin hustru: "Folk bombarderer mig nu atter med alle mulige sager, som jeg skal bringe $\mathrm{i}$ orden. Jeg bruger over $10 \mathrm{kr}$. ugentlig til porto, lidt over $2 \mathrm{kr}$. daglig. Og det er jo brødløst arbejde. ${ }^{39}$

Den største arbejdsbyrde var dog de politiske sager. Partiet valgte ham til sin ordfører i debatten om indfødsretsloven, loven om udstykning og sammenlægning af ejendomme i Sønderjylland samt loven om udstykning af de sønderjyske præstegårde. H.P. Hanssen blev også medlem af flere af Folketingets ad hoc udvalg (se nedenfor), hvortil kom sæde i Grønlandskommissionen og kommissionen vedrørende et jysk universitet. ${ }^{40}$ Venstre gjorde således brug af H.P. Hanssen. Først og fremmest, men ikke kun til de særligt sønderjyske sager.

\section{H.P. Hanssens arbejde med særligt sønderjyske sager}

Det første særligt sønderjyske spørgsmål, som H.P. Hanssen deltog i behandlingen af, var et forslag i rigsdagssamlingen 1924/25 om at indføre de kongerigske regler for fastsættelse af kapitelstaksten i Sønderjylland. Han tilsluttede sig forslaget, der var ganske ukontroversielt. ${ }^{41}$

I det store og hele kan det samme siges om landbrugsminister $\mathrm{Kr}$. Bordings forslag i samlingen 1924/25 om indskrænkninger i retten til jords udstykning samt om jords sammenlægning i de sønderjyske landsdele. I vid udstrækning byggede det på Neergaard-regeringens forslag, som var fremsat i samlingen 1923/24, men ikke blevet færdigbehandlet. Dog var det skærpet på to områder. Det oprindelige lov- 
forslag bestemte, at en landbrugsejendom ved frastykning ikke måtte gøres mindre end $1 \frac{1}{2}$ ha. Denne grænse ønskede den nye regering nu sænket til $1 / 2$ ha. Endvidere ønskede den indsat en overgrænse for, hvor stor en landbrugsejendom måtte gøres ved tilkøb af jord. Den blev i forslaget sat til 180 daler skyldudbytte, dog altid 16 ha. H.P. Hanssen kunne helt tilslutte sig, at lovforslaget ville harmonisere lovgivningen om udstykning og sammenlægning af landbrug i Sønderjylland med det øvrige land. Imidlertid foretrak han minimumsstørrelsen sat til $11 / 2$ ha, så selv de mindste landbrug kunne ernære en familie uden, at manden skulle tage arbejde uden for bedriften. Ligeledes fandt han det urimeligt, at ejendomme på 180 daler skyldjord og derover ikke kunne få tillagt mere jord. En ganske almindelig bondegård på 50-60 tønder land på den gode jord i Sundeved og på Als havde f.eks. nemt 400-600 daler skyldjord. Derfor ønskede han grænset sat "ret betydeligt op«. H.P. Hanssen kom med i det udvalg, der behandlede jordloven, men kunne ikke her komme igennem med sine synspunkter og endte med at undlade at stemme, da forslaget kom til tredjebehandling. ${ }^{42}$ Regeringens forslag blev vedtaget uændret i Folketinget af Socialdemokrater og Radikale. I Landstinget havde Venstre og Konservative imidlertid flertal. Et kompromis blev derfor nødvendigt, og det resulterede $i$, at mindstegrænsen i loven sattes til 1 ha, mens overgrænsen på de 180 daler helt bortfaldt. ${ }^{43}$

Af stor betydning for vestslesvigsk landbrug var landbrugsminister Bordings forslag i samlingen 1924/25 om afvanding af Tøndermarsken. ${ }^{44}$ Her var der ligeledes tale om et lovforslag overtaget fra den forrige regering. Der blev kun tale om ret ubetydelige ændringer. H.P. Hanssen anbefalede regeringens forslag og forsvarede de betydelige udgifter, som afvandingsarbejdet ville påføre statsfinanserne. Dog pegede han på en besparelsesmulighed ved at få elektricitet til pumpestationerne fra det nye Sønderjyllands Højspændingsværk i Aabenraa i stedet for at anlægge et særligt vandkraftværk i marsken. Landbrugsminister Bording lovede at overveje dette nøje. H.P. Hanssen kom også her med i det lovforberedende udvalg, som sluttede sig til hans forslag om elektriciteten, idet spørgsmålet blev overladt til ministerens afgørelse. Lovforslaget blev derefter vedtaget enstemmigt. ${ }^{45}$ Ministeren afgjorde senere, at Sønderjyllands Højspændingsværk skulle levere strømmen til pumpestationerne. ${ }^{46}$

Da afvandingsloven stod for at skulle justeres i samlingen 1925/26, henstillede H.P. Hanssen til finansministeren, at renten på lån til de 


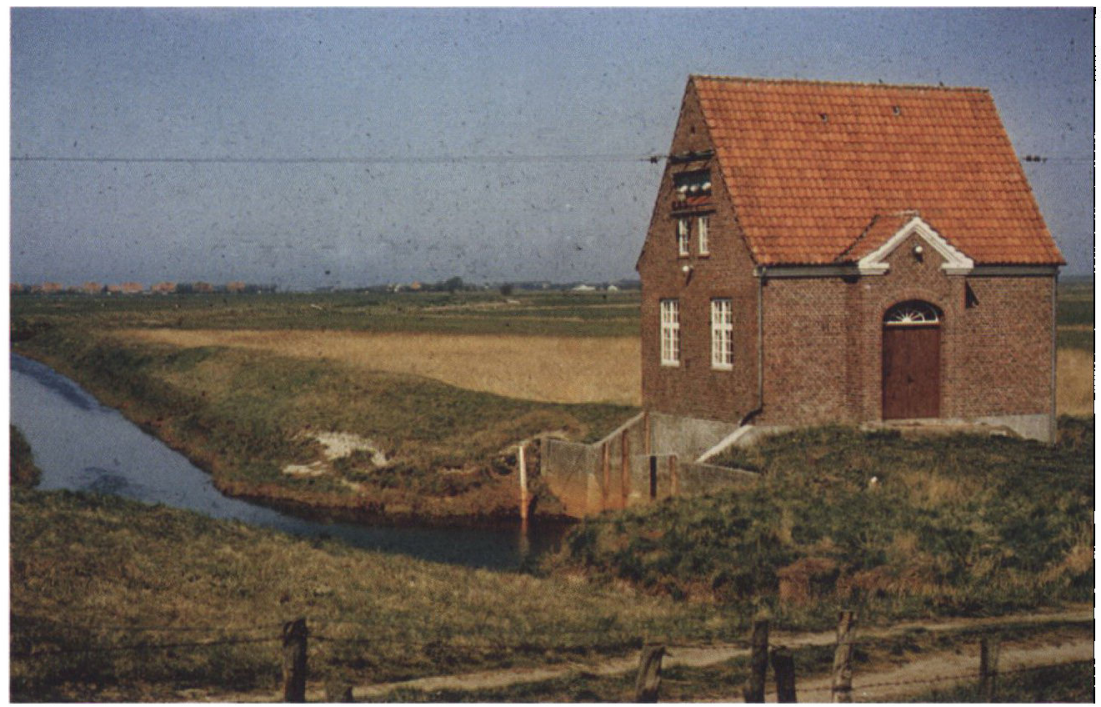

Reguleret og inddiget åløb med pumpestation $i$ Tøndermarsken efter afoandingen $i$ 1920'erne. Bemærk stromforbindelsen til Sonderjyllands Højspændingsværk $i$ Aabenraa. H.P. Hanssen foreslog, at strømmen blev købt her $i$ stedet for at oprette et vandkraftværk. Foto: Museum Sønderjylland - ISL.

medvirkende landmænd blev sat så lavt som muligt. Det var nemlig ifølge loven finansministeren, som skulle fastsætte renten. Oprindeligt var den tænkt at skulle være $4 \%$ årligt og afdragene $1 / 2 \%$, men blev alligevel i loven sat til $6 \%$ og afdragene til $1 \%$. Det havde skabt en betydelig opposition mod projektet i digelaget, som blev forstærket af den nye tyske toldtarif, der lagde hård told på importen af levende kreaturer og dermed reelt afskar marskbønderne fra deres traditionelle marked syd for grænsen. I nationalistiske kredse i Kiel havde man søgt at udnytte dette $i$ kampen for en grænseflytning. ${ }^{47}$

Da H.P. Hanssen blev medlem af Folketinget, var de første tegn på en økonomisk krise begyndt at vise sig, bl.a. ved et højt renteniveau. Finansminister C.V. Bramsnæs måtte derfor 1924/25 fremsætte et lovforslag, der udvidede Laanekassen for Sønderjyllands udlånsvirksomhed på to områder: Særlige lån til krigsinvalider, der ønskede at grundlægge egen virksomhed, og en generel udvidelse af lånekassens kapital. H.P. Hanssen tilsluttede sig ikke overraskende begge dele. Forslaget blev vedtaget enstemmigt. ${ }^{48}$

Så langt var de »sønderjyske sager« mestendels uden kontroversielt 
indhold. Anderledes stillede det sig med regeringens forslag i samlingen 1924/25 til ændring af lov af 1922 om indførelse af dansk kirkelovgivning i Sønderjylland. Forslaget rummede intet nyt i kirkelig henseende, men ville forpligte de sønderjyske præsteembeder til en udstykning af præstegårdsjorden til husmandsbrug, så snart jorden blev ledig $i$ henhold til de bestående præstelønnings- og forpagtningskontrakter. De kommende husmænd skulle ikke betale købesummen på én gang, men forrente den med $41 / 2 \%$ årligt. Således var det bestemt for det øvrige Danmark med loven af 4 . oktober 1919, og den socialdemokratiske regering ønskede en tilsvarende bestemmelse indført i Sønderjylland. Partiets sønderjyske folketingsmand, J.P. Nielsen, var en stærk tilhænger af dette.

H.P. Hanssen henviste i sin tale som Venstres ordfører til, at lovforslaget havde rejst et ramaskrig hos de sønderjyske menighedsråd. De havde netop set deres markkapitaler helt udhulet under den tyske hyperinflation, og denne dyrekøbte erfaring bød dem nu at holde fast ved sognekaldenes værdibestandige ejendom. Selv om H.P. Hanssen også på dette område ideelt set onskede en fuld harmonisering mellem de sønderjyske og kongerigske regler, og selv om han principielt gerne så udstykningen fremmet af sociale og nationale grunde, anbefalede han på Venstres vegne et nej til lovforslaget. En harmonisering burde udskydes af hensyn til de betrængte sønderjyske menighedsråd, og fordi der kunne fås rigeligt med jord til udstykning fra domænegårdene, men ikke nok menneskemateriale til at få alle de nye husmandsbrug besat. H.P. Hanssen anbefalede en forhandling mellem det udvalg, der skulle nedsættes, samt menighedsrådene og husmandsforeningerne for at løse problemet, så det ikke kom til at præge de kommende menighedsrådsvalg. ${ }^{49}$ H.P. Hanssen fik sæde i det udvalg, som Folketinget nedsatte. Det lykkedes dog ikke her at nå frem til et kompromis. H.P. Hanssen m.fl. foreslog at lade spørgsmålet om udstykning eller fortsat bortforpagtning af præstegårdsjorden afgøre ved en sogneafstemning. ${ }^{50}$

Under andenbehandlingen fremsatte H.P. Hanssen en interessant udtalelse om hastigheden i genforeningsprocessen: "Jeg tror ikke, man vil kunne bestride selve den kendsgerning, at befolkningen dernede lidt efter lidt lever sig ind $i$ den danske tankegang og gør sig mere fortrolig med danske synspunkter, man skal blot ikke tænke på at presse det hele $\mathrm{i}$ dem med eet, der må tid til at leve sig ind i de nye forhold ... « ${ }^{51}$ H.P. Hanssen erkendte og respekterede således sine 
sønderjyske landsmænds indgroede skepsis mod hurtige forandringer og indså nødvendigheden af at tage højde for den. Mange sønderjyske »særheder « havde dybe historiske rødder: »Det er virkelig mit alvorligste ønske, at vi så hurtigt som muligt kan nå frem til en ensartet lovgivning for hele riget, men vi må have de hindringer ryddet til side, der er en følge af en århundredlang forskellig historisk udvikling, og det lader sig ikke gøre med eet slag; dér må man vise nogen tålmodighed. «52 Derfor anmodede han indtrængende om, at forslaget blev afvist. ${ }^{53}$ Det blev imidlertid vedtaget med 72 stemmer imod 61 og sendt til videre behandling i Landstinget. Her havde Venstre og Konservative som nævnt flertal, og det forslag, som fremkom af behandlingen her, kunne folketingsflertallet ikke acceptere, og arbejdet blev indstillet. ${ }^{54}$ Først i 1949 blev de sønderjyske præstegårdes udstykning besluttet.

Et problem, som siden 1864 havde fyldt meget i den dansk-tyske konflikt om grænselandet, var statsborgerskabsforholdene. H.P. Hanssen havde stor erfaring med dette fra sin tid i den tyske rigsdag. Derfor blev han 1924/ 25 både Venstres ordfører i debatten om regeringens forslag til lov om erhvervelse og fortabelse af indfødsret og medlem af det udvalg, som behandlede lovforslaget. H.P. Hanssen havde en række indvendinger mod forslaget, der ikke havde specielle sønderjyske vinkler. Han tilhørte ikke desto mindre det flertal i udvalget, som anbefalede lovforslagets ved tagelse, hvilket også skete, oven i købet enstemmigt. $^{55}$

Beslægtet med indfødsretsloven var loven om tilsynet med fremmede og rejsende, som stod for revision i samlingen 1925/26. Ifølge den nye $\S 6$ måtte udlændinge ikke tage beskæftigelse i Danmark uden en arbejdstilladelse. Dette erklærede H.P. Hanssen sig helt enig i ud fra et sønderjysk standpunkt, der skulle sikre landsdelen mod at blive oversvømmet med fremmed, først og fremmest tysk, arbejdskraft. 56

H.P. Hanssen glemte ikke, at han var folketingsmand for Haderslev og Aabenraa kredse og slet ikke, at han også var valgt i sin hjemby Aabenraa. Således forsøgte han i 1924 at få gennemført ekspropriation af arealer i Aabenraa til en ny banegård. Minister for offentlige arbejder Johannes Friis-Skotte (S) lovede at tage dette med i ændringsforslaget. ${ }^{57}$ Som bekendt måtte Aabenraa imidlertid nøjes med sin gamle station, indtil banen Rødekro-Aabenraa blev nedlagt i 1970'erne. Omvendt talte han 1925/26 imod Haderslev og Aabenraa byers interesse, 


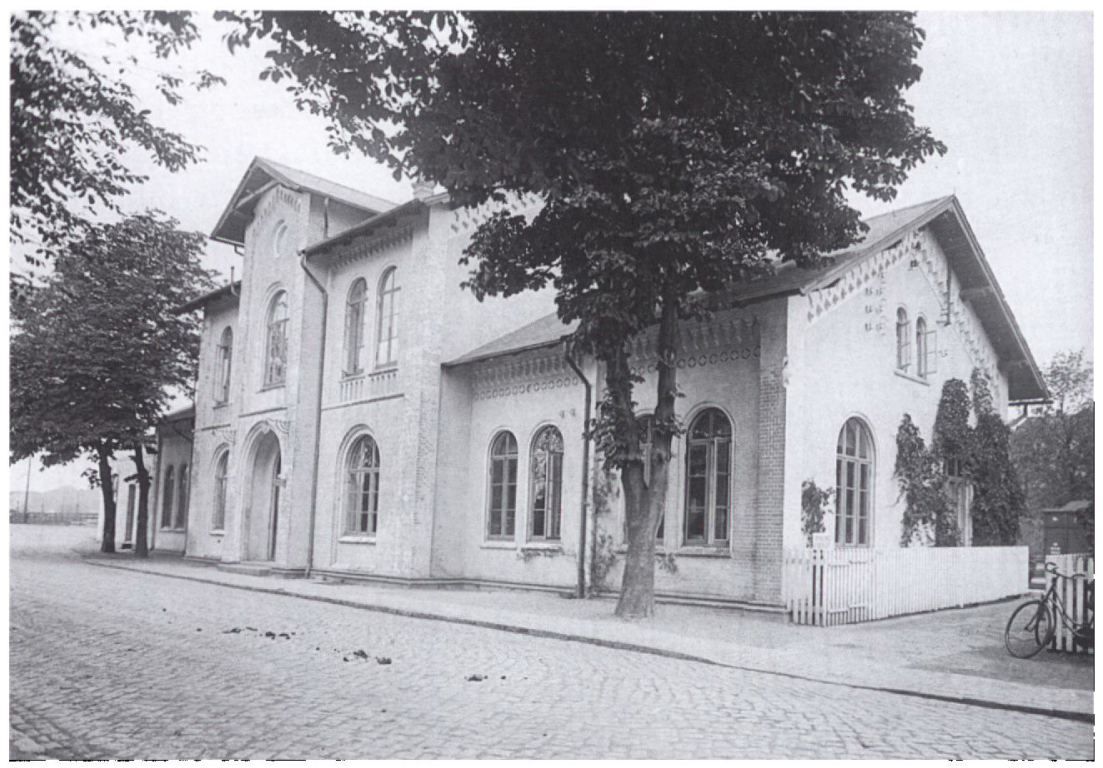

Aabenraa statsbanegård $i 1920^{\prime}$ erne. Havde det stået til H.P. Hanssen, var der blevet bygget en ny og starre banegaird. Det blev ikke til noget, og bygningen kan stadig nydes $i$ Aabenraas bybillede. Rudolf Olsen foto i Museum Senderjylland - ISL.

da han gik ind for forslaget om at afskaffe disse to byers og Københavns ret til herreløs arv. Han fandt, at det reelle udbytte af disse privilegier var meget ringe, og at ensartede bestemmelser for hele landet var vigtigere. ${ }^{58}$ Den samme indstilling prægede hans syn 1925/26 på den kommende tinglysningslov: de almindelige danske regler burde indføres i Sønderjylland. H.P. Hanssen fik her sæde i det udvalg, som blev nedsat. ${ }^{59}$

H.P. Hanssen plejede derimod en særlig sønderjysk interesse, da han i februar 1926 sammen med sine sønderjyske folketingskolleger J.P. Nielsen, P. Mortensen, Nis Nissen og C.O. Pedersen og landstingsmedlemmerne Jørgen Møller, Hans Jefsen Christensen, H.D. Kloppenborg-Skrumsager og Dr. Karberg vendte sig imod et konservativt forslag om nedlæggelse af Søndre Landsret i Sønderborg. ${ }^{60}$ H.P. Hanssen var medlem af det udvalg, som skulle behandle forslaget til ændringer i retsplejeloven, men udvalget nåede ikke at gøre sig færdig, før samlingen 1925/26 var forbi. ${ }^{61}$ For så vidt opnåede de sønderjyske rigsdagsmænd deres mål, men det blev kun en stakket glæde, eftersom Søndre Landsret forsvandt med udgangen af $1927 \mathrm{i}$ henhold til 
lov af 14 . juli 1927 om ændringer og tilføjelser til lov om rettens pleje. $^{62}$

I mellemkrigstiden var det tyske mindretal repræsenteret ved fhv. pastor Johannes Schmidt-Vodder. Ved finanslovsdebatten i november 1925 tog han ordet og krævede bl.a. kulturel autonomi for de tysksindede nordslesvigere. Det vakte H.P. Hanssens kritik, for Schmidt havde som repræsentant for det tyske mindretal i Danmark på den nyligt afholdte mindretalskongres i Genève undladt at stemme for en resolution herom, ifølge H.P. Hanssen fordi resolutionen havde slået fast, at kulturel autonomi skulle bygge på de bestående statsordninger, dvs. med udgangspunkt i de eksisterende grænser. Med andre ord var modviljen mod at fraskrive sig grænseflytningskravet vigtigere for Schmidt end kulturel autonomi. I øvrigt mente H.P. Hanssen, at den eksisterende mindretalsordning sikrede det vigtigste element $\mathrm{i}$ den kulturelle autonomi, fordi den gav forældrene mulighed for at bestemme over deres børns undervisning. ${ }^{63}$

\section{H.P. Hanssens stilling til forsvarsspørgsmålet}

Den eneste ikke-sønderjyske sag, som H.P. Hanssen for alvor engagerede sig i, var forsvarsspørgsmålet. $\mathrm{Og}$ så alligevel: et stærkt dansk forsvar var i sønderjydernes interesse, eftersom deres landsdel var mest udsat for angreb i tilfælde af krig.

Den nye socialdemokratiske regering fremsatte den 8. oktober 1924 ved forsvarsminister Laust Rasmussen et forslag om dansk afrustning. Hæren og flåden skulle afskaffes, og den almindelige værnepligt bortfalde. De frivillige korps skulle opløses. Til gengæld skulle der oprettes et politivagtkorps på ca. 7.000 mand for at opfylde de forpligtelser, Danmark havde i henhold til Folkeforbundstraktaten. Det skulle alene mobiliseres og indsættes "under givne situationer « til bevogtning af landegrænsen og kysterne og til opretholdelse af den indre ro og orden. Der skulle endvidere være en statsmarine, som skulle varetage kystbevogtning, fiskeriinspektion og søopmåling. ${ }^{64}$

Forslaget og den efterfølgende debat afspejlede, at forsvarsspørgsmålet havde været en ideologisk slagmark for de politiske partier siden 1880 'erne. For både tilhængere og modstandere af afrustningsforslaget var der i høj grad tale om et trosspørgsmål. Enten troede politikerne på, at Danmark kunne sikre sig fred ved at afruste, så landet ikke udgjorde en militær trussel for nogen, og så som ekstra 
gevinst spare store beløb, der i stedet kunne bruges til sociale formål. Eller også troede de på, at Danmark ved at have et militært forsvar kunne afholde andre magter fra at sætte sig i besiddelse af landet $\mathrm{i}$ tilfælde af en europæisk storkrig, det være sig gennem afskrækkelse eller ved at skabe tillid hos de omkringliggende lande til, at Danmark havde vilje til at forsvare sit eget territorium, så de ikke behøvede at gøre det. Neutralitetspolitikken var der derimod bred enighed om.

Venstres forsvarsordfører var Søren Brorsen, der helt afviste forslaget. Den 27. november 1924 tog H.P. Hanssen ordet. Det skete sikkert på baggrund af den stærke modstand, der hurtigt viste sig mod forslaget i Sønderjylland. Den 18. oktober havde omkring 40 sønderjyske konservative og venstrefolk været samlet til et møde i Tinglev, hvor de havde vedtaget et opråb "Til det danske Folk! «, som de ville indsamle underskrifter på. Det henviste til nødvendigheden af et forsvar mod tyske grænserevisionskrav og slog fast: "Vi vil ikke udleveres! « ${ }^{65}$ Selv om Hejmdal erklærede sig imod afrustningsforslaget, lagde avisen - og dermed H.P. Hanssen - nogen distance til opråbet, der var affattet $\mathrm{i}$ ret stærke vendinger. ${ }^{66}$ Den planlagte adresse synes ikke at være blevet til noget.

I sin tale fremhævede H.P. Hanssen, at den danske neutralitet måtte være en væbnet neutralitet. Dette synspunkt støttede han på sine erfaringer som tysk rigsdagsmand under Verdenskrigen. Der var dengang to perioder, hvor Danmark var $i$ fare for at blive angrebet af Tyskland, august 1914 og oktober 1916. I august 1914 bidrog den danske mineudlægning, sammen med de sønderjyske soldaters pligttro fremmøde ved deres afdelinger, til at give tyskerne tillid til, at Danmark ville forsvare sin neutralitet med våbenmagt $\mathrm{og}$ hindre, at dansk territorium blev brugt som opmarchområde for et angreb på Tyskland. I oktober 1916, ved optakten til den uindskrænkede ubådskrig, stod der efter oplysninger, som H.P. Hanssen havde fået, tre armékorps klar til at invadere Danmark, og den tyske generalstab var $i$ færd med at trykke kort over Danmark. Invasionen blev ikke til noget, fordi tyskerne netop da var bundet så stærkt op i Rumænien, at de nødvendige tropper ikke kunne afses, og i stedet anlagde tyskerne Sikringsstilling Nord som et værn imod et angreb nordfra. Ifølge Hanssen illustrerede dette, at en stormagt nok har mange tropper, men også mange fronter at tage vare på, og i et sådant tilfælde kunne selv en ret beskeden dansk hær rykke ved marginalerne for et angreb, så dette aflystes. H.P. Hanssen var ikke principielt imod afrustning, 


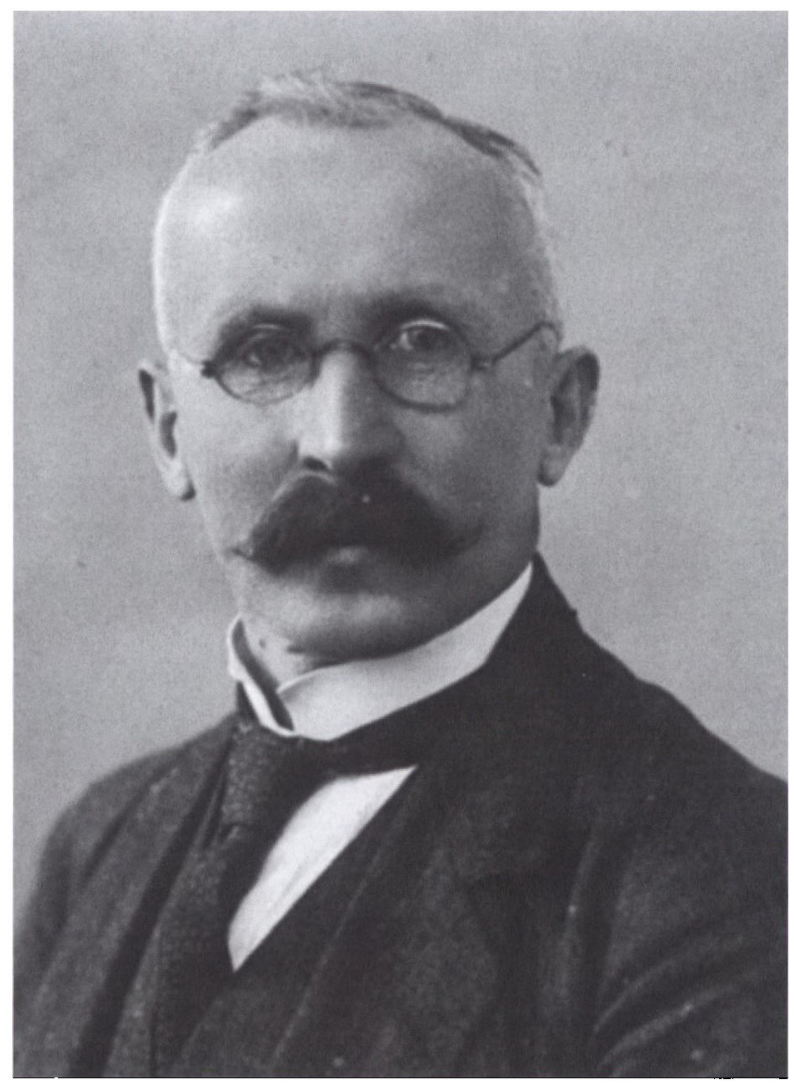

Nis Nissen (1878-1960) fra Viby var 1908-18 medlem af den preussiske landdag. Ligesom H.P. Hanssen valgte han i forste omgang at stå uden for dansk politik, men lod sig i 1924 vælge til Folketinget for Det Radikale Venstre. Hans karriere $i$ Folketinget blev lige så kort som H.P. Hanssens, for $i 1926$ trådte han ud. Foto: Museum Sonderjylland - ISL.

men den måtte ikke ske isoleret, men i takt med andre lande. Han sluttede sit indlæg med ordene: "Jeg vil slutte med at sige, at vor afsky for krigen ikke er mindre dyb, vort had til krigen ikke mindre glødende end regeringspartiets. Når vi desuagtet ikke kan stemme for de foreliggende forslag, er det, fordi de efter vor overbevisning ikke svækker, men skærper, ikke mindsker, men øger faren for, at Danmark kan blive krigsskueplads i en kommende krig. « ${ }^{67}$

H.P. Hanssens gamle kampfælle, Nis Nissen (R), tog også ordet i forsvarsdebatten. Også han kunne henvise til personlige erfaringer 
fra Første Verdenskrig, nemlig som sanitetssoldat. På denne baggrund og som radikal stottede han afrustningsforslaget. H.P. Hanssens tale fik positive kommentarer både fra Venstres hovedstadsblad Kobenhavn og fra den radikale Politiken. Sidstnævnte bemærkede, at afrustningsdebatten var de to ledende sønderjyders reelle debut i Folketinget, og at de med deres taler begge havde højnet Folketingets niveau. ${ }^{68}$ H.P. Hanssen selv undrede sig noget over debatten. På et vælgermøde i Aabenraa sagde han sikkert ganske rammende: »Når man har overværet debatterne, der er ført herom, måtte man tænke på de teologiske diskussioner i gammel tid, hvor talerne bombarderede hinanden med skriftsteder. « ${ }^{69}$

H.P. Hanssen fik sæde i det udvalg, som skulle behandle lovforslaget. ${ }^{70}$ Som ventet kunne udvalget ikke nå frem til en enig indstilling. Socialdemokrater og Radikale gik sammen om et fælles forslag. H.P. Hanssen og de andre venstremænd afgav en mindretalsindstilling, der ville fastholde forsvarslovene af 1922 som ramme for Danmarks værn. De konservative repræsentanter afgav ligeledes en mindretalsindstilling. ${ }^{71}$ Det socialdemokratisk-radikale forslag blev vedtaget i Folketinget, men blev standset af Venstre og Konservative i Landstinget, hvor de to partier havde flertal. Danmark blev ikke afrustet.

\section{H.P. Hanssen beslutter sig til ikke at genopstille}

I sine breve hjem til fru Helene i Nygade i Aabenraa besværede H.P. Hanssen sig allerede fra oktober 1924 jævnligt over sit skrantende helbred. Han led af en bronkitis, som især gjorde det svært for ham at tåle tobaksrøg. Det var længe før, rygning blev forbudt på Christiansborg og rygerne henvist til særlige rygekabiner anskaffet for dyre penge. Der blev røget godt og grundigt til møderne. Og møder var der mange af. H.P. Hanssen sukkede flere gange over de lange dage, det gav, f.eks. i januar 1926: »Det er strenge måneder at komme igennem. I găr havde jeg to udvalgsmøder om formiddagen,

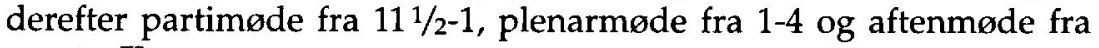
$7-11 / 2 ! \ll^{72}$

Til klagerne over røgen kom tvivlen om, hvorvidt arbejdsevnen slog til. Endnu i begyndelsen af december 1925 mente H.P. Hanssen at have fysik til arbejdet: "Med al min skrøbelighed er jeg dog glad over, at jeg kan klare en pynt som den i sidste uge. Der er jo i virkeligheden ikke så mange, der $\mathrm{i}$ en alder af henad 64 år kan udholde et 
par natterejser og alle dertil hørende strabadser så godt som jeg. Og det gode er, at hverken natterejserne eller presset med talerne i øvrigt synes at trætte min arbejdslyst eller arbejdsevne. Det er værd at takke for. Thi vel er det tit besværligt at være overlæsset med arbejde, men jeg tror ikke, jeg kunde udholde at være uden arbejde. «3 $^{73}$ Men i januar 1926 beklagede han over for Helene: „Om nogen tid er arbejdsevnen måske så svækket, at jeg ikke kan mere. « $^{74}$

Dertil kom nu en faldende interesse for det parlamentariske arbejde. I slutningen af december 1925 skrev han til Helene: »Jeg er træt og ked af den hele parlamentariske virksomhed. Det er alt for meget lovjaskeri og lovflikkeri - ikke tid til at sætte sig grundigt ind i nogen enkelt sag, altid er man henvist til i vid udstrækning at stole på andre. « $^{75} \mathrm{Og}$ senest $\mathrm{i}$ januar 1926 synes afgørelsen at være truffet: »Hovedsagen er, at jeg bliver fri for at modtage genvalg. Min tid som politiker er omme, når der ikke sker noget særligt, som kalder mig, og det er der ikke udsigt til i den tid, jeg endnu kan deltage. Det daglige arbejde her kan ikke fange min interesse. ${ }^{76}$

H.P. Hanssen var imidlertid pligttro og sad valgperioden ud. Men hans længsel efter et valg var stærk. I oktober 1926 betroede han Helene: »Vi har haft et overordentlig skarpt sammenstød mellem regeringen og de Radikale i dag. Forholdet er brudt, og det er den almindelige mening, at vi får valg i november. Til julen er jeg så fri for mandatet! Glæd dig, o, min pige! - til forårs rejser vi så sydpå, måske allerede i februar ... Jeg føler det som en befrielse, at jeg kan se ende på det. «77 På dette tidspunkt havde H.P. Hanssen for længst meddelt folketingsgruppen og sine to opstillingskredse, at han ikke ønskede genvalg, begrundet med hensynet til helbredet. Der opstod spekulationer i pressen, om det nu kunne være den rigtige begrundelse. Nogle antog, at H.P. Hanssens tilbagetræden skyldtes uenighed med resten af Venstre. Det afviste Hejmdal. ${ }^{78}$ Det havde næppe heller noget på sig; han nævnte i hvert fald ikke noget om en sådan splittelse i brevene hjem til Helene. Skal der peges på et andet motiv end helbredet, var det snarere manglende interesse for folketingsarbejdet, men den kunne jo også bunde i svigtende sundhed.

Valget blev udskrevet til den 2. december 1926. H.P. Hanssen deltog i valgkampen for Venstre, men partiets forgrundsskikkelse i Sønderjylland blev denne gang fhv. landbrugsminister Th. Madsen-Mygdal, der netop var blevet opstillet i Røddingkredsen. Det skete ved en veltilrettelagt aktion på Venstres møde for partiets rigsdagsmænd, or- 


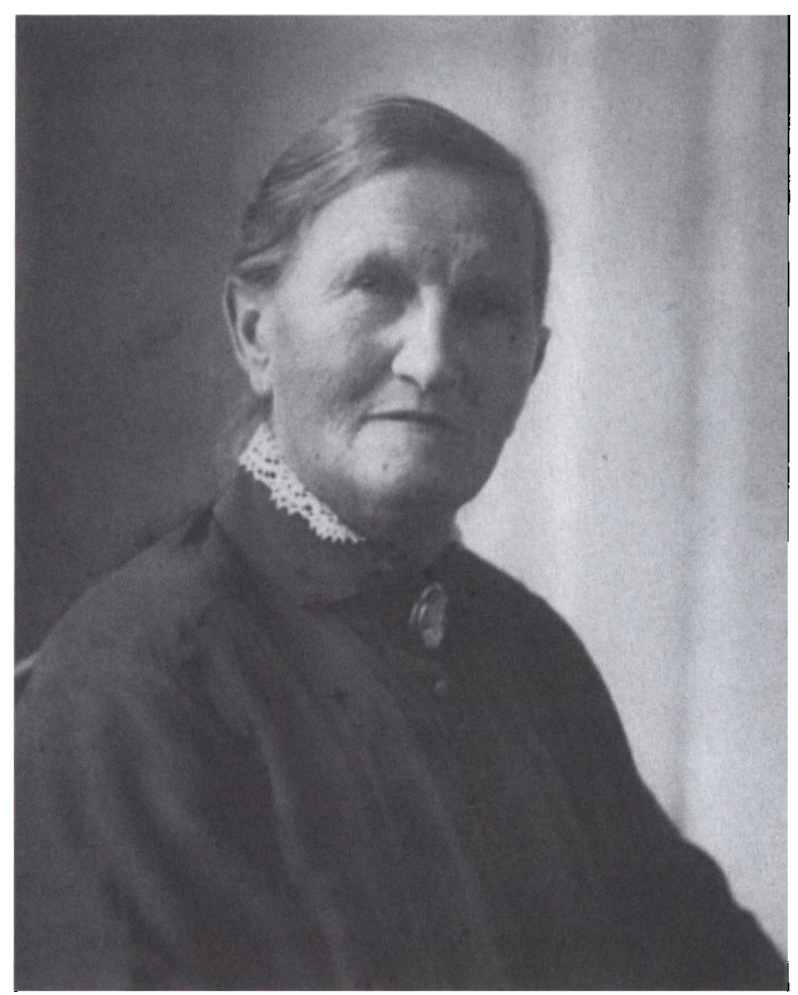

Helene Hanssen (1860-1935) var H.P. Hanssens nærmeste fortrolige, også i politiske spargsmål. Det fremgår af de breve, han sendte til hjemmet $i$ Nygade, mens han sad $i$ Folketinget. De viser, at H.P. Hanssen $i$ samlingen 1925/26 lob træt $i$ det politiske arbejde på Christiansborg. L. Christensen foto 1925 i Museum Senderjylland-ISL.

ganisationsledere, redaktører og kandidater den 10. november 1926. Her opnåede Mads Gram ikke alene at få den højtprofilerede venstremand opstillet i Sønderjylland, men reelt også kåret ham som Venstres nye leder og statsministerkandidat. ${ }^{79}$

H.P. Hanssen var godt tilfreds med forløbet. Den 11. november skrev han til Helene: "I går klarede Mads Gram sig udmærket, meget skal være ham tilgivet derfor. Som du vil have set, hørt, får vi Madsen Mygdal opstillet i Rødding kredsen. Det var det bedste under den foreliggende situation både under hensyn til landbrugskrisen, som nu står i forgrunden, til Selvstyrebevægelsen, amtsforvalteren og de Konservative. $\mathrm{Nu}$ vil der snart stå kampgny ud over landet. Jeg er foreløbig meget tilfreds. Øjeblikkets opgave er løst, - dermed er ikke 
sagt, at også fremtidsopgaven er løst. Men kommer tid, kommer råd. Jeg kan nu i år få en rolig jul. Valgbevægelsen må jeg selvfølgelig støtte, men når valget $\mathrm{d}$. 2 . dcbr er overstået, kan jeg hvile ud efter sommerens og efterårets travle arbejde.« Amtsforvalteren var C.O. Pedersen, H.P. Hanssens partifælle, med en udpræget sympati for en grænse syd om Flensborg.

Der var ikke vemod at spore hos H.P. Hanssen ved hans exit fra dansk politik. Hertil bidrog sikkert også en positiv oplevelse: »Da jeg gik ned ad Strøget for et par dage siden og et øjeblik stod ud for et vindue, blev jeg tiltalt af en yngre velklædt mand. "De kender ikke mig“, sagde han, »det er også ligegyldigt, hvem jeg er, jeg er en mand fra gaden, som med sorg har set, at De opgiver politikken, og derfor foler trang til at sige Dem hjertelig tak for, hvad De har været for Danmark«. Så trykkede han min hånd og gik! 80 $^{80}$

\section{Sammenfatning}

Overordnet blev H.P. Hanssens tid i Folketinget 1924-26 en tam affære. Det lå allerede forud $\mathrm{i}$ kortene, at det let kunne gå således. Det var nærmest umuligt at nå højderne fra årene som enlig repræsentant i den tyske rigsdag for de danske sønderjyder, kulminerende med rejsningen af grænsespørgsmålet $\mathrm{i}$ efteråret 1918, og siden tiden som minister $\mathrm{i}$ den danske regering med forberedelsen af Genforeningen som hovedopgave.

H.P. Hanssens hovedinteresse var de særlige sønderjyske sager. Bortset fra selve grænsespørgsmålet var der her tradition for bred enighed imellem partierne. Den blev med få undtagelser ført videre af den socialdemokratiske regering i de få tilfælde, hvor love fra 1920 skulle gås efter i sømmene, og i den nye lovgivning f.eks. om Tøndermarskens afvanding. De sønderjyske sager rummede mere rutine end lidenskab.

Omvendt nærede H.P. Hanssen ikke den store interesse for de sager, som traditionelt var kontroversielle i Folketinget. Forsvarssagen var eneste større undtagelse, som bekræftede reglen. Derudover engagerede H.P. Hanssen sig ikke meget $i$ andre sager; det skulle da lige være den nye straffelov, som blev grundigt diskuteret i Venstre, og hvor H.P. Hanssen ytrede sig klart for en afskaffelse af dødsstraffen, og jagtloven, hvor han kom i det udvalg, der skulle behandle loven; han var passioneret jæger. ${ }^{81}$ Fordelingspolitikken havde aldrig været 


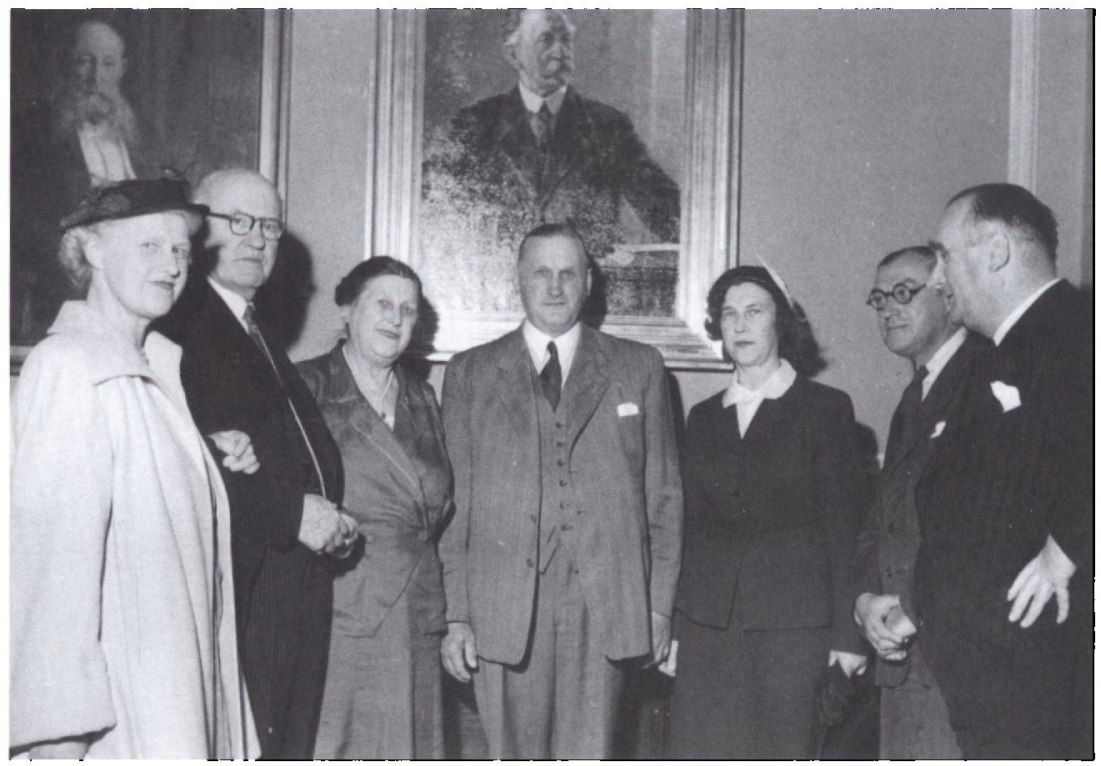

Selv om H.P. Hanssens tid på Christiansborg blev kort, er det velbegrundet, at hans portræt findes her. Her ses ved afsløringen fra venstre døtrene Thyra og Ingeborg og sonnerne Peter Christian og Bjorn. Yderst til hojre Gustav Pedersen, Folketingets formand 1950-64. Politiken foto i Museum Sønderjylland - ISL.

hans gebet, da han i sit tidligere virke måtte føre politik for alle sociale grupper blandt de dansksindede sønderjyder. Den økonomiske politik gik han heller ikke meget op i; den fyldte ellers meget i midten af 1920 'erne i forbindelse med kronens opskrivning til pari og de vanskeligheder, denne skabte. Dertil kom, at det tydeligvis ikke lå til H.P. Hanssens temperament at spare på skillingen, $\mathrm{i}$ hvert fald ikke $\mathrm{i}$ grænselandet. På det punkt var han en atypisk venstremand.

Grundlæggende har denne undersøgelse således ikke rokket ved, at årene i det danske Folketing 1924-26 blev en tvivlsom oplevelse for H.P. Hanssen og under alle omstændigheder en parentes $i$ hans politiske liv. Den kan dog ikke bekræfte Svend Thorsens meget mørke syn på H.P. Hanssens sidste 15 leveår: at de overvejende stod i et tragisk lys. Dette forudsætter næsten som udgangspunkt, at H.P. Hanssen stilede efter en karriere i første række i dansk landspolitik. Denne undersøgelse viser, at det gjorde H.P. Hanssen på ingen måde; han gik ind i Folketinget for at varetage særlige sønderjyske interesser. Thorsens billede af H.P. Hanssen som en nærmest nedbrudt mand stemmer heller ikke 
med Hanssens mangesidede virke i den sønderjyske landsdel. Således var han knap nok nået ud af Folketinget, før han spillede en central rolle i oprettelsen af Foreningen Landeværnet ved årsskiftet 1926/27. Formentlig var Thorsens vinkel lige lovlig Christiansborgsk.

Undersøgelsen har derudover bragt nuancer ind det gennemgående grå billede. Selv om ikke alle modtog H.P. Hanssen venligt på Christiansborg, var det de fleste. Umiddelbart følte han sig godt hjemme i Venstre. Som forholdene nu engang var for et parti, der gik fra regering til opposition, må man tilsvarende sige, at Venstre gav H.P. Hanssen en position i gruppen og i udvalg og kommissioner, som lå pænt ud over, hvad nye gruppemedlemmer ellers fik tilbudt.

Nogen udpræget partigænger blev H.P. Hanssen aldrig. Hverdagens partitaktiske lillekrig på Borgen og på vælgermøderne interesserede ham ikke. Her var han på linje med de fleste andre sønderjyder, der ikke var vokset op med dansk parlamentarisk tradition. Måske spillede det også ind, at han i Berlin havde kunnet udvælge sine sager selv og ikke været en del af en fraktion. Nu måtte han slide i det for løbende at medvirke til folketingsgruppens formulering af Venstres politik. Arbejdet fik snart et omfang, hvor det blev rigeligt selv for H.P. Hanssen.

Der spores endelig en betydelig forskel på H.P. Hanssens engagement $\mathrm{i}$ folketingssamlingerne 1924/25 og 1925/26. Sidst på året 1925 kørte han træt. De helbredsproblemer, der hidrørte fra en bronkitis og forværredes af den udbredte rygning ved møderne, medvirkede til at fratage ham appetitten på det parlamentariske arbejde. H.P. Hanssen så fra denne tid kun frem imod det næste valg, så han kunne blive fri for sine sure pligter - men det trak ud et helt år. Det er sandsynligt, at han som folge heraf mere og mere isolerede sig selv og blev mere isoleret $i$ partiet og $i$ tinget - og at dette har været med til at farve opfattelsen af hele hans tid i Folketinget sort i sort.

\section{KILDER OG LITTERATUR}

Utrykte kilder

LAA. Landsarkivet for Sønderjylland,

H.P. Hanssens arkiv (personarkiv nr. 272):

Nr. 17-18: Breve fra H.P. Hanssen til Helene Hanssen 1916-30.
Nr. 77: Breve fra forskellige NagelNielsen, breve fra og til Niels Neergaard 1923.

Nr. 166: Korrespondancesager vedr. H.P. Hanssens virksomhed som dansk rigsdagsmand 1920-35.

Uordnet tillæg bl.a. med sager fra folketingsarbejdet. 
Trykte kilder

Folketingstidende 1924, 1924/25 og $1925 / 26$.

Folketingsvalget den 11. April 1924. Statistiske Meddelelser 4.71.1. Kobenhavn 1924.

Hejmdal 1923-26.

Kilder til den dansk-tyske grænseregions historie/Quellen zur Geschichte der deutsch-dänischen Grenzregion, IV, Aabenraa/Schleswig 2001.

Lovtidende 1925.

\section{Litteratur}

Andersen, Morten: Den folte grænse. Slesvigs deling og genopbygning 19181933, Aabenraa 2008.

Dam-Jensen, Elsemarie m.fl. (red.): Det grænselose landskab, Tonder 2008.

Eller, Soren: "Indgreb i marsklandets sjældne og særegne skønhed «. Diskussionen om afvanding og naturfredning i Tøndermarsken 1925, Sønderjyske Arbøger 2011, s. 9-44.

Fink, Troels: H.P. Hanssen som minister $i$ regeringen Zahle 1919, Aabenraa 1977.

Fink, Troels: Da Sønderjylland blev delt 1918-20, I-III, Aabenraa 1978-79.
Fink, Troels: Båndene bandt, I-II, Aabenraa 1999.

Hanssen, H.P.: Fra Kampaarene, I-II, Kbh. 1928-29.

Jessen, Franz von: Haandbog $i$ det slesvigske Sporgsmaals Historie, III, Kobenhavn 1938.

Jargensen, Harald (udg.): To Ungdomsvenner. H.P. Hanssen - H.V. Clausen. En brevneksling, Aabenraa 1962.

Lausten-Thomsen, H. (red.): Bogen om H.P. Hanssen. Skrevet af hans Venner, Kobenhavn 1948.

Refshauge, P.J.: Bonden der blev Landraad, Tonder 1941.

Refslund Thomsen, Ingeborg: Hjemme i Nordslesvig, Aabenraa 1961.

Schmidt Poulsen, Agnes: "Etableringen af partiet Venstre i Nordslesvig efter 1920«, Sonderjyske Arboger 1977, s. 118-177.

Sonderjyllands Historie V, København 1932-33.

Thorsen, Svend: Delt efter anskuelser. Den politiske partidannelses forleb $i$ Sonderjylland efter genforeningen $i$ 1920, København 1970.

Thorsen, Svend: De danske ministerier. 1901-1929, København 1972.

\section{NOTER}

1. Redaktør C.J. Bech: "De sidste Aar« i Lausten-Thomsen (red.), s. 217238 , citat fra s. 217.

2. Fhv. udenrigsminister Laust Moltesen: "Som jeg kendte ham i i Lausten-Thomsen (red.), s. 89-94, citat fra s. $93 \mathrm{f}$.

3. Thorsen: Delt efter anskuelser, s. 98f.

4. Hanssen II, s. 164 (foredrag på årsmodet 1910).

5. Sonderjyllands Historie V, s. 139, 182, 197. Fink: Båndene bandt I, s. 145, 277f. Jorgensen (udg.), s. 3 (H.P. Hanssen til H.V. Clausen 28.3.1887). Se også sst., s. 27 .

6. Thorsen: De danske ministerier, s. 308.

7. Se herom Schmidt Poulsen.

8. Se herom Fink: H.P. Hanssen som minister.

9. Fink: Da Sønderjylland blev delt III, s. 86f, 92, 96f, 139-141.
10. Se herom Schmidt Poulsen.

11. Refshauge, s. 153f.

12. Referat af deputationernes fremmøde med aftryk af deres og Refshauges og Lebecks henvendelser $\mathrm{i}$ Hejmdal 19.9.1923.

13. Thorsen: Delt efter anskuelser, s. 95. Jf. Refshauge, s. 153.

14. LA $\AA$, H.P. Hanssens arkiv nr. 272/ 77, kopi af til brev til Neergaard 21.9.1923, Neergaards første svar 22.9. og andet svar 24.9.1923.

15. Hejmdal 26.9.1923.

16. Kilder til den dansk-tyske grænseregions historie IV, s. 413.

17. Talrige presseklip i Hejmdal mellem 19.9. og 28.9.1923.

18. Citeret efter Hejmdal 27. og 28.9. 1923.

19. Citeret efter Hejmdal 25.9.1923.

20. Hejmdal 26.9.1923.

21. Citeret i Hejmdal 27.9.1923. 
22. Talen gengivet i Hejmdal 3.12.1923.

23. Ref. af programtalen i Haderslev og mødet her i Hejmdal 12.2.1924.

24. Ref. af talen i Aabenraa og mødet her i Hejmdal 10.3.1924.

25. Hejmdal 12. og 13.3.1924.

26. Ref. af mødet i Rødekro i Hejmdal 22.3.1924.

27. Ref. af modet i Genner i Hejmdal 24.3.1924.

28. Ref. af mødet i Felsted i Hejmdal 2.4.1924.

29. Ref. af mødet i Uge i Hejmdal 26.3.1924.

30. Se omtaler i Hejmdal 25.3.-11.4.1924.

31. Ref. af modet i Kliplev i Hejmdal 8.4.1924.

32. Valgtal 1924 fra Folketingsvalget den 11. April 1924. Valgtal fra 1920 von Jessen III, s. 221-224. For en tolkning af valget, se Thorsen: Delt efter anskuelser, s. 90-99.

33. Det opfordrede således gdr. $M$. Refslund Poulsen fra Bovlund til, se Hejmdal 3.4.1924.

34. Refslund Thomsen, s. 119f, udtalelse fra Peter Grau 1947.

35. Folketingstidende 1924, sp. 14, 475. Folketingstidende 1925/26, sp. 299.

36. LA $\AA$, H.P. Hanssens arkiv nr. $272 / 17$, brev til Helene Hanssen 29.4.1924.

37. Kort over Folketingssalen 1924 i H.P. Hanssens arkiv nr. 272/166.

38. H.P. Hanssens arkiv nr. 272/17, brev til Helene Hanssen 28.5.1924.

39. H.P. Hanssens arkiv nr. 272/18, brev til Helene Hanssen 20.1.1925.

40. H.P. Hanssens arkiv nr. 272/17, breve til Helene Hanssen 24.5. og 25.10 .1924 samt nr. 272/18, breve af 17.2. og 5.3.1925.

41. Folketingstidende $1924 / 25$ sp. 2603.

42. Sst., sp. 3213-16, 5369, 5424f. Tillæg B, sp. 525-536.

43. Lovtidende 1925, s. 618-620.

44. Se herom generelt Eller.

45. Folketingstidende $1924 / 25$, sp. 566263, 5671, 6428-29, 6465. Tillæg B, sp. 1513-14. Lovtidende 1925, s. 758-760.

46. Dam-Jensen m.fl. (red.), s. 60 .

47. Folketingstidende $1925 / 26$, sp. 2499 og 2809 f samt $2812 \mathrm{f}$.

48. Folketingstidende $1924 / 25$, sp. 5239$40,5242-43,5419$.

49. Sst., sp. 5491-5497.
50. Sst., sp. 5575. Tillæg B, sp. 15151518.

51. Folketingstidende 1924/25, sp. 55475551.

52. Sst., sp. 6431-6433.

53. Sst., sp. 6470.

54. Folketingstidende 1924/25. Tillag B, sp. 2671.

55. Folketingstidende $1924 / 25$, sp. 46114618, 4640-41, 6407-09, 6465. Tillæg $B$, sp. $1485-1490$.

56. Folketingstidende $1925 / 26$, sp. 6583 . Se om denne problematik Andersen, s. 137-141 og 251-261.

57. Folketingstidende 1924, sp. 269-71.

58. Folketingstidende 1925/26, sp. 5208.

59. Sst., sp. $5968 \mathrm{f}$ og 5979.

60. Sst., sp. 4691.

61. Sst., sp. 4708, og Tillæg B, sp. 2713.

62. Landsarkivet for Sønderjylland. En arkivoversigt (2003), s. 99.

63. Folketingstidende 1925/26, sp. $1539 f$.

64. Folketingstidende $1924 / 25$, sp. 33-47.

65. H.P. Hanssens arkiv, uordnet tillæg, R.P. Rossen til H.P. Hanssen 11.11. 1924 med opråbet som bilag. Brevet var også sendt til venstremanden C.O. Pedersen og den konservative Holger Andersen.

66. Hejmdal 1.11.1924.

67. Folketingstidende $1924 / 25$, sp. 23622367.

68. Citeret i Hejmdal 29.11.1924.

69. Hejmdal 1.12.1924.

70. Folketingstidende 1924/25, sp. 2486, og 1925/26, sp. 3296.

71. Folketingstidende 1924/25, Tillæg B, sp. 2545-2554.

72. LAA, H.P. Hanssens arkiv nr. 272/ 18, brev til Helene Hanssen 22.1. 1926.

73. Sst. brev 6.12.1925.

74. Sst. brev 22.1.1926.

75. Sst. brev 18.12.1925.

76. Sst. brev 22.1.1926.

77. Sst. brev 21.10.1926, se også 24.10 . og 6.11.1926.

78. Hejmdal 8.11.1926.

79. Se herom Thorsen: Delt efter anskuelser, s. 108-111.

80. LÅ̊, H.P. Hanssens arkiv nr. 18 , H.P. Hanssen til Helene Hanssen 11.11.1926.

81. Sst. brev 18.1.1925 og Folketingstidende $1925 / 26$, sp. 182. 


\section{Zusammenfassung}

H.P. Hanssen, der bei den dänischen "sønderjyden" eine führende Position einnahm, hielt sich bei der Wiedervereinigung 1920 von jeglicher Stellungnahme bezüglich der Parteienpolitik in Dänemark fern. Erst im Jahre 1923 liess er sich als Kandidat zum Folketing für die liberale Partei Venstre aufstellen. Er bestrebte sich, die Interessen der dänischen "sønderjyden" im Folketing wahrzunehmen, eine Karriere in der dänischen Politik gehörte nicht zu seinen Hauptanliegen. 1924 wurde er ins Folketing gewählt. Trotz seiner Stellungnahmen aus der Zeit des Grenzstreites 1918-20 wurde er von fast allen Seiten gut empfangen. Als Politiker im Folketing engagierte er sich hauptsächlich in Verhältnissen, die mit Sønderjylland zu tun hatten wie zum Beispiel Landaufteilung, Entwässerung der Tøndermarsch, Erhaltung des Søndre Landsret (Landesgericht Süd) usw. Die Themen der aktuellen dänischen Landespolitik - mit Ausnahme der Verteidigungsfragen interessierten ihn kaum. Gesundheitliche Probleme führten bei Jahreswechsel 1925/26 dazu, dass H.P. Hanssen sein Interesse an der parlamentarischen Arbeit verlor und bei der Wahl im Dezember 1926 nicht wieder aufstellte. 